\title{
TERÙN: uma reflexão sobre o colonialismo epistemológico
}

\section{Terùn: a reflection on epstemological colonialism}

\author{
Tomás Cajueiro ${ }^{1}$
}

\begin{abstract}
Resumo: "Térun" é uma reportagem fotográfica que dá voz às pessoas que vivem na ocupação "Marielle Vive", organizada pelo Movimento dos Sem Terra (MST) na cidade de Valinhos, que propõe uma reflexão sobre as maneiras pelas quais as pessoas julgam o que é diferente e como as oportunidades de aprendizado são simplesmente perdidas por esses julgamentos. Faz isso com base na discussão sobre como o colonialismo tem sido há séculos uma constante na história da América Latina. Ao focar na violência epistemológica e os impactos culturais do colonialismo, este ensaio se baseia no trabalho de pós-colonialistas para destacar como esse aspecto importante e de alguma forma subdesenvolvido do colonialismo ainda está presente nas sociedades latino-americanas contemporâneas. Um continente que, como sabemos hoje, faz parte da história europeia muito mais do que parte da história dos habitantes originais dessa localização geográfica.
\end{abstract}

Palavras-chave: Movimento Sem Terra, Colonialismo, Ocidentalismo, Fotografia.

\begin{abstract}
Abstract: "Térun" is a photo reportage that gives voice to people living at the occupation "Marielle Vive", organized by the Landless Movement (MST) in the city of Valinhos, that propose a re?ection on the ways in which people judge what is different and how opportunities of learning are simply lost by those judgments. It does so based on the discussion about how colonialism has been for centuries a constant in Latin American history. By focusing on episteme violence and on the cultural impacts of colonialism, this essay draws on the work of post-colonialists to highlight how this important, and somehow underdeveloped, aspect of colonialism is still present on contemporary Latin American societies. A continent that as we know today is part of European history much more then it is part of the history of the original inhabitants of that geographical location.
\end{abstract}

Key Words: Landless movement, colonialism, occidentalism ,photography.

\section{A questão da identidade}

Durante séculos a América Latina sofreu as pragas do colonialismo e, apesar disso, ainda é uma região culturalmente rica e diversificada. Os impactos do colonialismo foram profundos e múltiplos. Das muitas posições antagônicas que explicam o que

\footnotetext{
${ }^{1}$ Tomás Cajueiro é Bacharel em Ciências da Comunicação pela Universidade para Estrangeiros de Perugia, Itália, e Mestre em Política Internacional pela Universidade de Manchester, Reino Unido. Conclui, em 2016, um MBA em Gestão Cultural na Fundação Getúlio Vargas, São Paulo. Atua no Brasil e no exterior como fotógrafo e produtor cultural desenvolvendo projetos de fotografia documental com forte cunho etnográfico. tomas@cajueiroproducoes.com.br
} 
é, este ensaio entende o colonialismo como uma multiplicidade de empreendimentos voltados à conquista de pessoas, terras, posses e, principalmente, de sua subjetividade. O colonialismo, ao contrário de outras formas de exploração, funciona sob a presunção de que a inferioridade dos outros é tal que eles simplesmente são incapazes de vê-la e, portanto, precisam ser ensinados - às vezes até com força - a seguir o caminho da civilização. A partir dessa perspectiva, a conquista da América tem o papel central de dar à luz o sujeito moderno (Todorov, 1984; Dussel, 2002), pois foi no processo de conquista que as colônias europeias e as elites crioulas criaram sua própria identidade (Dussel, 1993) e suprimiram epistemologias diferentes daquelas dos colonizadores. Consequentemente, a ideia de que a Europa é o locus privilegiado da enunciação de onde o "resto do mundo é descrito, conceituado e classificado" (Mignolo, 2008: 35) ganhou terreno e foi, alguns séculos depois, a base sobre a qual a Europa constrói seus impérios. Mas torna-se também a base sobre a qual os movimentos sociais nas últimas décadas têm estremecido os fundamentos da sociedade latino americana.

Evidentemente vivemos em uma sociedade diferente em comparação com a da América colonizada. Na era da informação e do soft power, as "lutas mais radicais ... ocorrem no campo de batalha do conhecimento e do raciocínio" (Mignolo, 2008: 100) e, portanto, é desnecessário colonizar as formas tradicionais. Colonizam-se ideias. Nessa ótica os movimentos sociais latino americanos, muitos dos quais surgem e lutam para terem suas narrativas aceitas como legítimas dentro dessa situação de violência epistemológica, são um excelente campo de estudo para compreendermos essas vozes forçadamente silenciadas. Apesar das enormes diferenças, todos esses movimentos são unidos por exigências de que sua voz seja ouvida e que seu espaço seja respeitado nas sociedades latino-americanas.

A ideia subjacente que guia este ensaio é que, para que América Latina supere muitos de seus desafios contemporâneos, suas elites e líderes devem parar de emular eventos que acontecem em outras sociedades - principalmente na Europa Ocidental e nos Estados Unidos - e, em vez disso, devem começar a procurar respostas dentro de seus próprios tecidos sociais. Pode parecer uma afirmação óbvia, mas em uma realidade social em que a colonialidade, como definida por Quijano (2007), reinou com tanta força, superar sua lógica está longe de ser simples. A maioria da população nunca fez parte do 
processo de construção da nação e foi marginalizada política, social e economicamente por uma matriz colonial de poder que tem suas raízes nos primeiros dias da colonização europeia. Apesar de poucas revoluções reprimidas as poderosas elites de América Latina haviam governado quase sem contestação até o final do milênio, quando uma nova situação política começou a surgir.

Acredito que o primeiro passo para mudar essa situação e dar um espaço meIhor às vozes até agora silenciadas pela colonialidade e pelo ocidentalismo, é valorizar formas de conhecimento produzidas fora das categorias modernas. Em suma, conhecimento que vai além da ideia de que a Europa é o único local válido de enunciação. É hora de tirar o véu que o ocidentalismo colocou em nossos olhos e começar a procurar diferentes tipos de conhecimento que podem ser muito mais úteis para entender os desafios e a demandas que surgem da sociedade internacional e multicultural que surge no século XXI. Há razões significativas para fazê-lo: de uma perspectiva humanística impõese o respeito e o reconhecimento tão esperados que as culturas "subalternas" merecem, algumas das quais estavam há mais de meio milênio sob pressões do ocidentalismo. Por outro lado, de maneira mais pragmática, deveríamos fazê-lo por uma constatação já feita por numerosos estudiosos: simplesmente não existem soluções modernas para muitos dos problemas de hoje (Escobar, 2004; Barkawi e Laffey, 2006; Giannetti, 2016). Crises financeiras, ecológicas e pobreza generalizada no terceiro mundo são apenas alguns dos desafios que a modernidade parece incapaz de resolver. Parece, seguindo essa tendência do pensamento acadêmico, que a tão falada história do fim, com a inevitabilidade do neoliberalismo e da democracia, está longe de ser verdadeira.

Se, de fato, estamos em uma situação em que, em vez do fim da história, deveríamos estar falando sobre o fim das ideias hegelianas da história, onde a Europa não é mais necessariamente a meta a ser alcançada (Dussel, 1993), então devemos começar a tomar muito mais seriamente a força epistêmica das histórias locais e pensar a teoria através das práticas políticas dos grupos subalternos. Culturas que, como observa Dussel (2002: 221), responderam diferentemente ao processo de colonização europeia, mas, apesar de marginalizadas, não perderam seu "núcleo ético-mítico". Eles entendiam a epistemologia europeia, enquanto, ao terem negadas suas agências, não eram entendidos pelos europeus pelo que são, mas eram entendidos pelo que o ocidentalismo Ihes 
permitia ser. Nos últimos anos, com o declínio e a ilusão da modernidade difundidos pela América Latina, há um grande aumento de grupos sociais emergindo das sombras da colonialidade (Quijano, 2005).

No entanto, para que um diálogo não eurocêntrico aconteça com essas culturas e, portanto, para que elas sejam totalmente aceitas pelo que são, precisamos desenvolver um "tipo de pensamento que se mova ao longo da diversidade do processo histórico ... [e ] se envolver com o colonialismo da epistemologia ocidental (da esquerda e da direita) da perspectiva de forças epistêmicas que foram transformadas em formas de conhecimento subalternas (tradicionais, folclóricas, religiosas, emocionais etc.) "(Mignolo, 2005: 9 -11). Em vez de homogeneizar a globalização, o foco deve ser um processo de pluriversalismo. Em termos zapatistas, um mundo onde muitos mundos se encaixam. Uma "hermenêutica pluritópica" (Escobar, 2004: 219) que permite a possibilidade de pensar além do ocidentalismo.

\section{Terùn: MST, colonialismo e a cegueira histórica}

É dentro dessa ótica da valorização de discursos subalternos que se posiciona o ensaio aqui apresentado. "Térun" é um ensaio fotográfico que dá voz aos acampados da ocupação "Marielle Vive" organizada pelo Movimento Sem Terra na cidade de Valinhos/SP. Um trabalho que busca, ao mesmo tempo, tirar aprendizados relativos à organização social da comunidade e refletir a cegueira histórica que ainda é gerada por esse colonialismo epistemológico que produz sujeitos que ignoram a própria história e, ao aceitarem a narrativa dominante, reproduzem discursos que no passado atingiram seus próprios antepassados.

Era abril de 2018 quando em Valinhos, no interior de São Paulo, um grupo de agricultores do MST teve a corajosa atitude de ocupar as terras de uma fazenda há muitos anos improdutiva. A histórica luta por terra em nosso país chegava a uma cidade que nas últimas décadas tem tido na especulação imobiliária o pilar de seu desenvolvimento. Em poucas semanas, a Ocupação "Marielle Vive" passou a ocupar também o imaginário coletivo da população, pautando os debates da pacata cidade do interior paulista. Pessoas tomavam lado, embates aconteciam, opiniões se contrastavam e, claro, fatos eram criados sem ter nenhuma relação com a realidade. Parecia que em um toque de mágica 
os Valinhense eram peritos em reforma agrária. Mesmo assim, os acampados não eram ouvidos. Nunca. Debatia-se sobre eles, sem dá-los a necessária voz.

"Terún” é uma palavra que, assim como Valinhos, tem origem Veneta. "Terún”, em italiano terrone, é aquele que vem da terra, que trabalha a terra. Palavra cujos primeiros registros remetem aos anos do Ressurgimento italiano, quando assim se referiam os aristocratas a parcela da população que trabalhava na agricultura. Inicialmente sem conotação negativa, mas tampouco positiva, "Terrone" estava para o italiano muito como o termo "Camponês" está para o brasileiro. Curiosamente, foram justamente eles, os agricultores do nordeste italiano, que imigraram as novas terras na América do Sul fugindo da miséria. Valinhos, então ainda um distrito de Campinas, recebe em massa parte desses imigrantes.

Passaram-se os anos e a Itália, assim como Valinhos, se urbanizou, criou indústrias, se tornou uma potência. Essa nova Itália, pós-guerra, vê ressurgir e ganhar força e um novo uso a palavra "Terrone". Dessa vez não mais neutra e objetiva, mas com forte carga semântica negativa. "Terrone" se refere ao imigrante do sul do país que foi para o rico e industrializado norte atrás de oportunidades. São massas de pessoas que vivem nas periferias de Milão, Turim, Genova e tantas outras cidades da Itália setentrional. Pejorativamente, esses imigrantes são chamados "Terrone". No século XX, o termo "Terrone" é um insulto. É ser preguiçoso, ser ignorante.

Valinhos tem suas origens fortemente ligadas ao nordeste da Itália. Foram os "Terrone" do século XIX que, com muito suor, construíram a história da próspera cidade. No dialeto Veneto, "Terrone" são chamados "Terún". Dai nasce o nome do ensaio, que visa fazer refletir sobre nossos julgamentos sobre realidades que não conhecemos e como, paradoxalmente, os filhos e netos dos "Terrone" de outrora, agora julgam os acampados com termos e ideias que se encontram no mesmo, racista, campo semântico que julgou seus antepassados. Falassem italiano, o valinhense, infelizmente, se referiria aos acampados como "Terún". Um ensaio que visa refletir sobre como aos nos colocarmos de maneira tão firme dentro dos limites impostos pelo ocidentalismo acabamos por ser incapazes de enxergar os movimentos sociais que emergem das beiradas do colonialismo uma fonte legitima de conhecimento. Fonte essa que poderia, em um momento no qual 
tanto se fala em crise de democracia, uma base para reflexões profundas sobre novas maneiras de organizarmos a sociedade.

\section{Considerações Finais}

A América Latina do século XXI apresenta uma infinita fonte de possibilidades para quem tem interesse em estudar novos modelos de desenvolvimento para as sociedades contemporâneas. Apesar da onda populista que tem tomado o continente nos últimos anos, os movimentos sociais vem ganhando força e já não podem ser ignorados. Força essa que foi impulsionada no início do século quando lideres do campo progressista dominaram o cenário político do continente e produziram legislações que deram voz e solidificaram a atuação desses movimentos. Parte de um reflexo do amadurecimento de instituições democráticas, líderes políticos como Chávez, Lula, Morales, Kirchner e outros, começaram a surgir e mudar a face política latino americana.

Considerando o impacto cultural discutido do colonialismo e, especialmente, como os países que surgiram após a queda dos impérios europeus não foram uma consequência das lutas locais, mas sim da emulação de desenvolvimentos que aconteciam em um continente europeu que lutava contra o monarquismo (Mignolo, 2008: 65-68), a América Latina pós-independência viu surgir estados independentes mas compostos por sociedades ainda muito coloniais (Quijano, 2000), criando um contexto social que agora está sendo desafiado por essa nova classe política e pelas organizações civis que foram consolidadas no novo século.

Esse trabalho considera as experiências de acampamentos e/ou assentamentos do Movimento Sem Terra, assim como tantas outras manifestações populares oriundas dessas culturas ?subalternas?, uma fonte inesgotável de conhecimento. O aprendizado coletivo, a empatia com as necessidades básicas dos indivíduos, mas, sobretudo, as reflexões oriundas de um diferente modelo de desenvolvimento, são oportunidades que infelizmente se perdem diante de uma sociedade ainda cega pelas pragas do ocidentalismo. As fotos aqui apresentadas mostram os primeiros 12 meses de um acampamento que em 2020 completa o seu segundo aniversário. Desde os primeiros dias, da sua constituição, que é registrada nesse projeto, até os dias de hoje, muita coisa aconteceu no acampamento, alcançando resultados positivos além dos seus portões: em uma terra 
até então considerada infértil, surgiu uma produção agrícola que está a todo o vapor e parte dela é doada ao hospital de Valinhos; além disso células de ensino foram criadas dentro da comunidade, possibilitando a alfabetização de pessoas que, até então, nunca tiveram acesso a um sistema de ensino; dentre tantas outras facilidades e oportunidades que surgiram do amadurecimento do acampamento e das oportunidades de um sistema de democracia participativa. No entanto, um unica coisa não mudou: o ódio de grande parte da população de Valinhos em relação aos moradores do Marielle Vive. Ódio esse que se manifesta através de comentários em redes sociais, em rodas de conversas, mas que também ganha forma física. Infelizmente no dia 18 de julho de 2019 o acampado Luís Ferreira da Costa, de 72 anos, foi atropelado e morto durante uma manifestação, em frente ao acampamento, que reivindicava melhorias nos serviços básicos, como acesso a água. Luiz, assim como tantos outros, estava lutando por melhores condições de vida em um país extremamente desigual e estava prestes a se formar na escola de alfabetização de jovens e adultos que funcionava no local. Ele aprendeu a ler a escrever pelas mãos dos acampados do "Marielle Vive"(G1, 2020), e morreu pelas mãos daqueles que um dia foram imigrantes mas hoje rejeitam sua própria história.

\section{As fotografias}

Em um primeiro momento as fotografias registram os primeiros dois meses da ocupação "Marielle Vive", entre abril e Maio de 2018. Imagens registram os pioneiros, aqueles que chegaram em uma situação política ainda instável para lutar por um pedaço de terra e construir seus sonhos. Registram o surgimento, os primeiros passos e esperanças de um espaço que hoje é ocupado por mais de 1.000 famílias. Passados alguns meses, em janeiro de 2019, voltei a ocupação para, dessa vez, acompanhar a evolução da comunidade que agora tem mais de 5.000 pessoas e, portanto, desenvolveu uma série de mecanismos para a gestão dos espaços e atividades comuns. Em tempos em que debatemos possibilidades para as nossas democracias, olhar além das tradicionais fontes de conhecimento pode revelar-se uma experiência surpreendente.

\section{Referências}

BARKAWI, Tarak; LAFFEY, Mark. The Postcolonial Moment in Security Studies. In Review of International Studies, v.32, n. 2, p. 329-352, 04/2006 
DUSSEL, Enrique. Eurocentrism and Modernity (Introduction to the Frankfurt Lectures. In Boundary 2 ? postmodernism debate in Latin America. v. 20, n. 3, p. 65-76, 1993

DUSSEL, Enrique. World-system and trans-modernity. Neplanta: Views from the South. v. 3,n. 2,p. 221-244, 2002

ESCOBAR, Arturo. Beyond the third world: Imperial Globality, Global Coloniality and anti-globalization social movements. Third World Quartly. v. 25, n. 1,p.207-230, 2004

GIANNETTI, Eduardo. Trópicos utópicos: Uma Perspectiva Brasileira da Crise Civilizatória. Companhia das Letras. São Paulo. 2016

MIGNOLO, Walter. The idea of Latin America. Blackwell Pubblishing. Oxford, 2005

MIGNOLO, Walter. The geopolitics of knowledge and the colonial difference. In. MORAÑA, Mabel.; DUSSEL, Enrique.; JÁUREGUI, Carlos A., (eds). Coloniality at Large: Latin America and the Postcolonial Debate. Duke. Duke University Press, 2008, p. 225258

QUIJANO, Anibal. ?Coloniality of Power, Eurocentrism and Latin America?. In Neplanta:Views from the south. V, 1 N. 3, P. 533-579, 2000

QUIJANO, Anibal. The challenge of the ?indigenous movements? in Latin America. In Socialism and Democracy. V.19, n. 3,p. 55-78, 2005

QUIJANO, Anibal. ?Coloniality and modernity/rationality? in Cultural Studies v.21 p.2, p.168 178, 2007

TODOROV, Tzvetan. The conquest of America: the question of the other. University of Oklahoma Press, Nova lorque, 1984

IDOSO morto em ato do MST trabalhava de pedreiro e era aluno de escola de alfabetização para adultos da ocupação.G1,Campinas 18 de Jul. de 2019. Disponível em <https://g1.globo.com/sp/campinas-regiao/noticia/2019/07/18/idoso-mortoatropelado-em-ato-do-mst-ia-se-formar-na-escola-da-ocupacao-faltavam-15-aulas-dizprofessora.ghtml> Acesso em 10/03/2020 
Figura 1. Construção dos primeiros barracos: De um terreno vazio para um bairro com 5.000 moradores em poucas semanas.

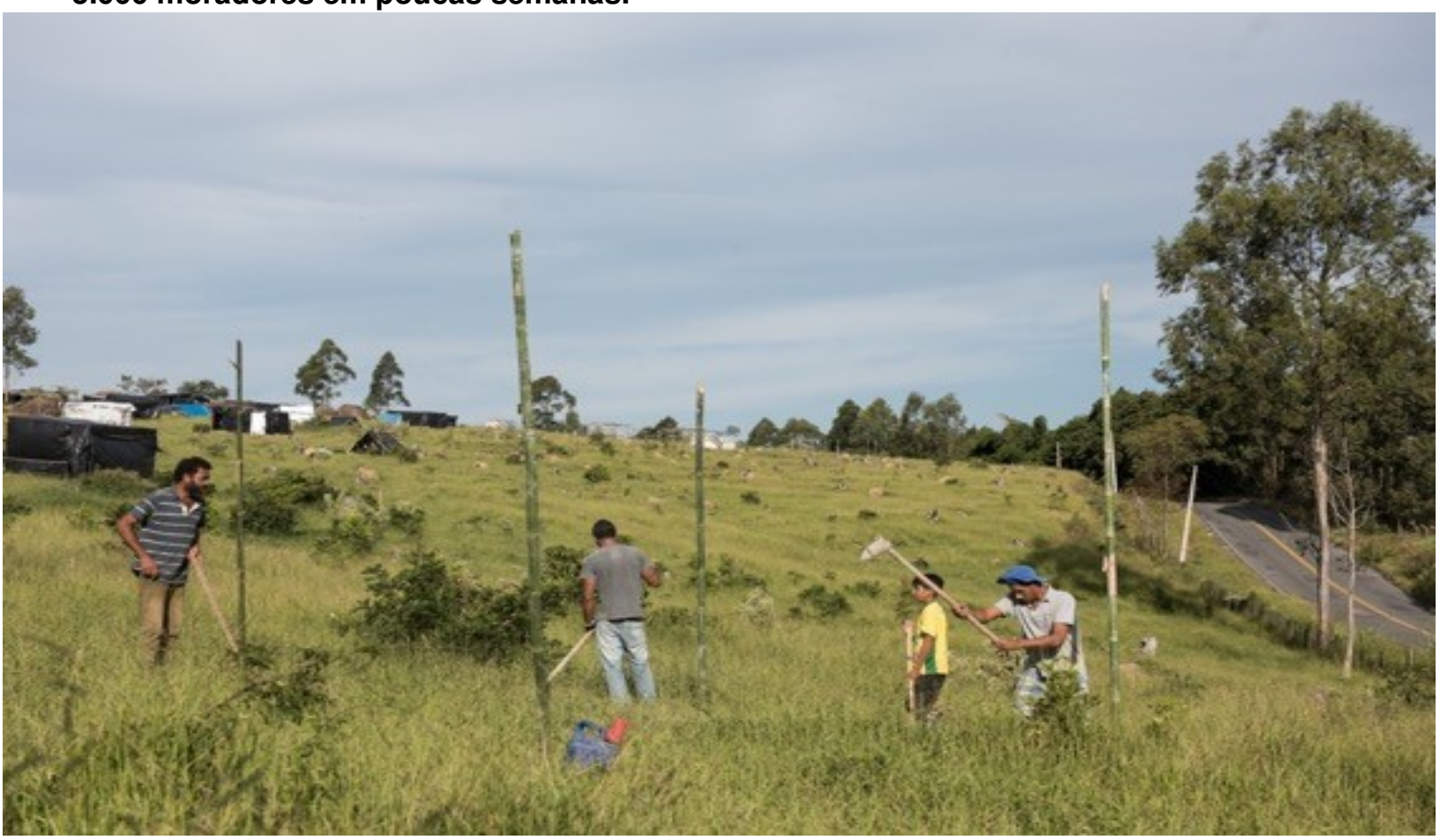

Figura 2. Construção dos barracos: nas primeiras semanas os acampados dormem em estruturas improvisadas com bambu e lona.

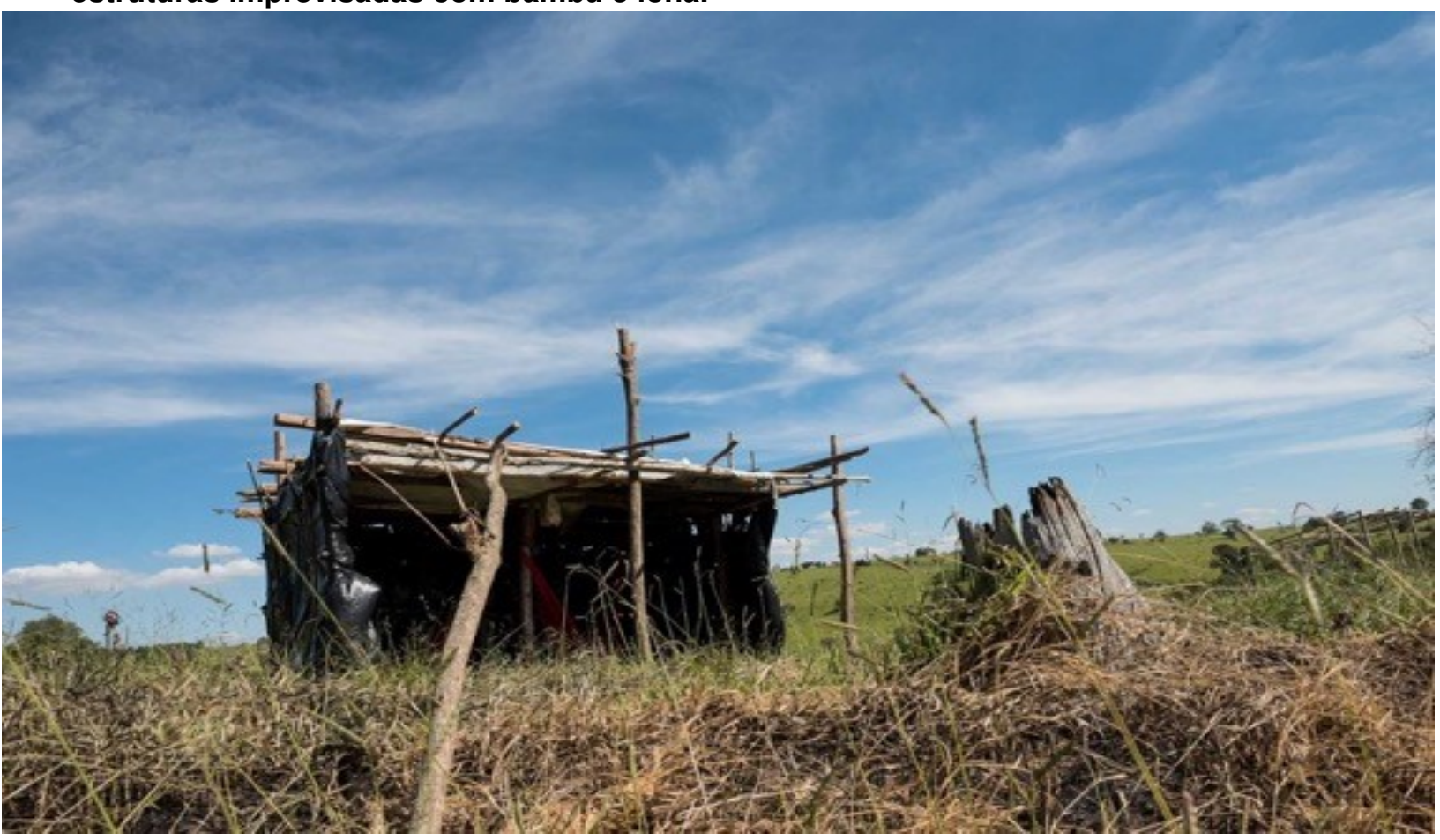


Figura 3. Construção dos barracos: um dos mais fascinantes aspectos é a troca de conhecimento entre diferentes gerações. A oralidade se torna o principal meio de transmissão de saber

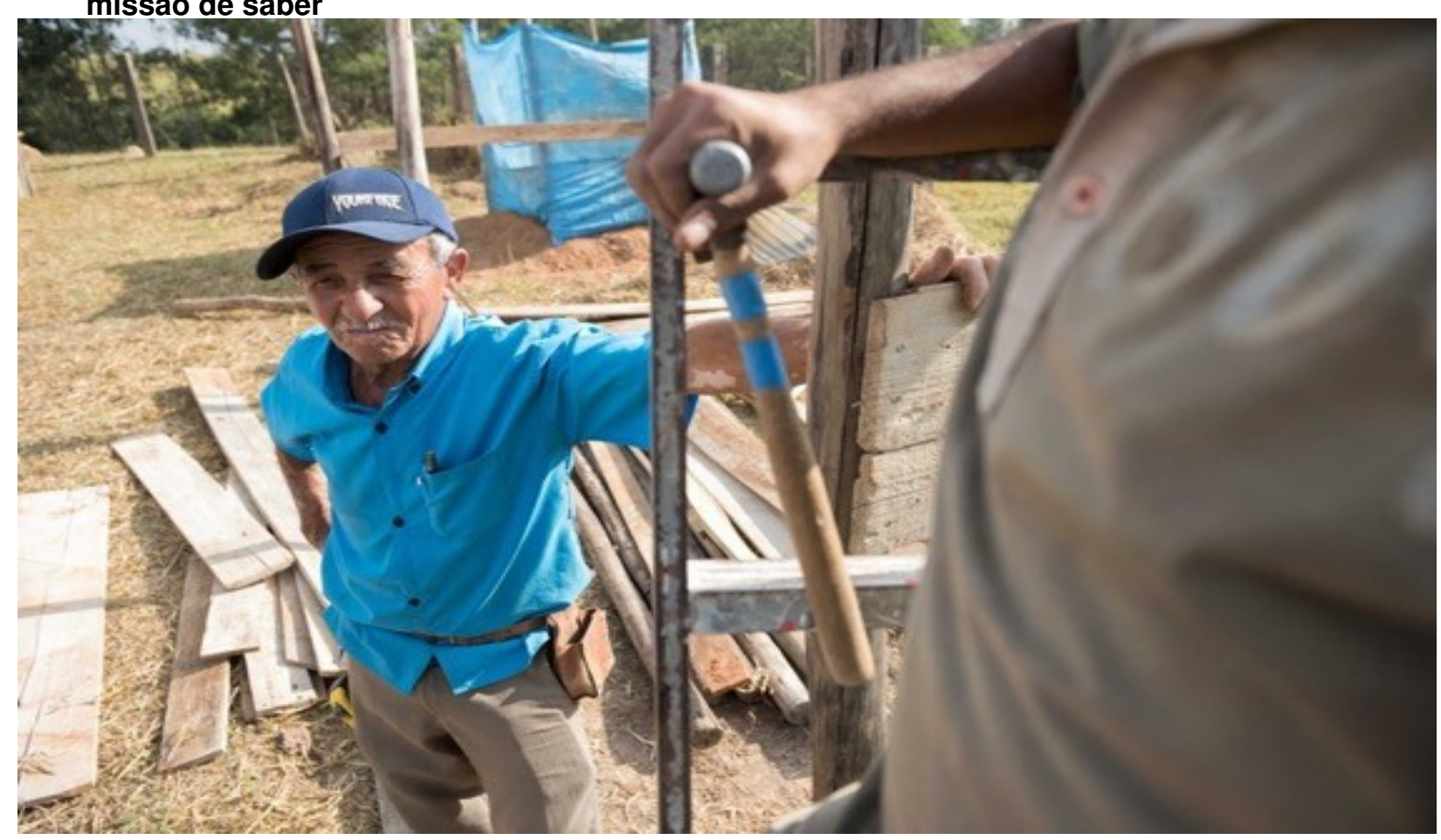

Figura 4. Construção dos barracos: longos dias de trabalho marcam a ocupação

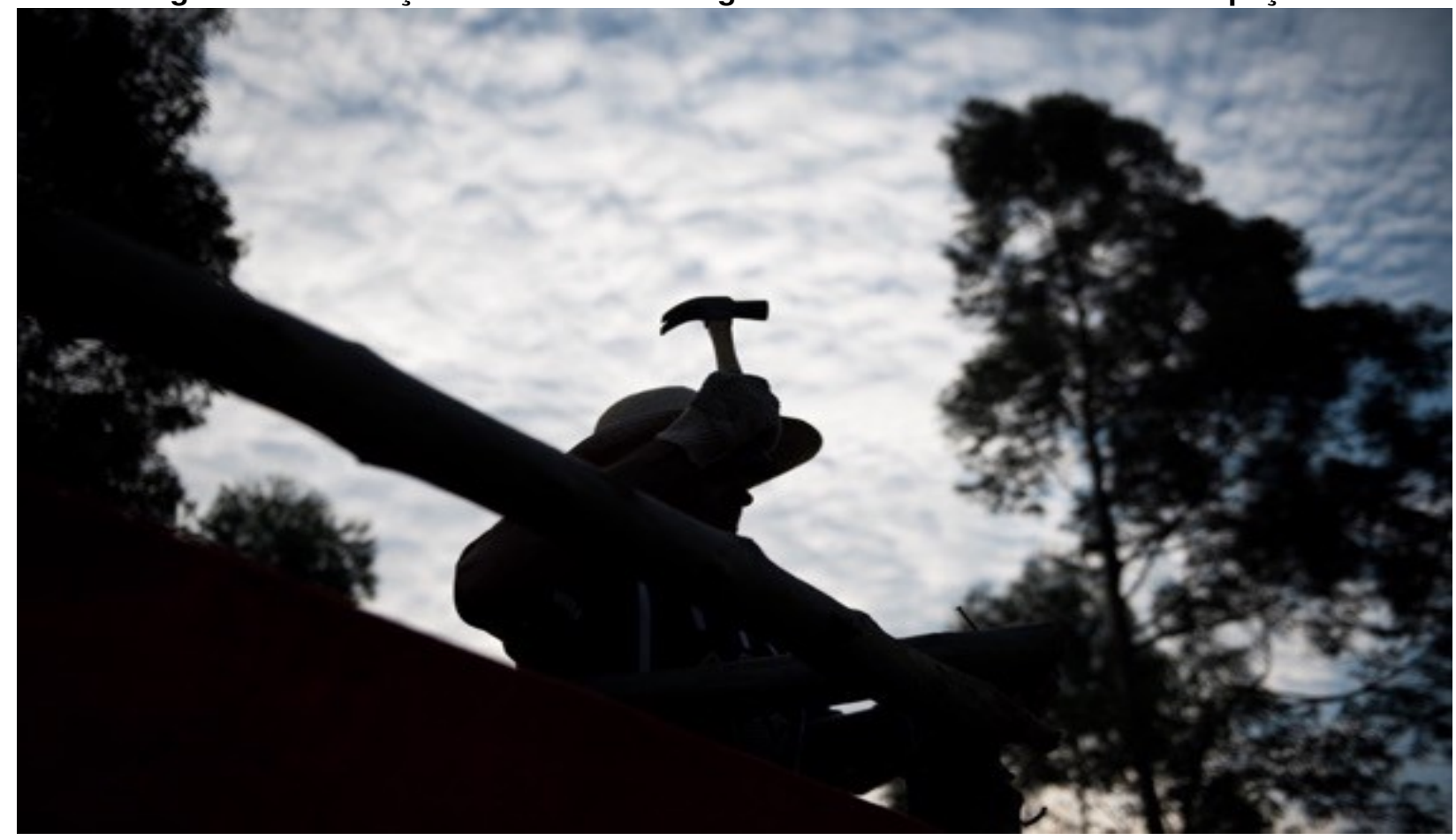


Figura 5. Construção dos barracos: acampados constroem barracos de todos os tipos, inclusive com dois andares, assim podem dormir no segundo andar e portanto protegidos de animais peçonhentos

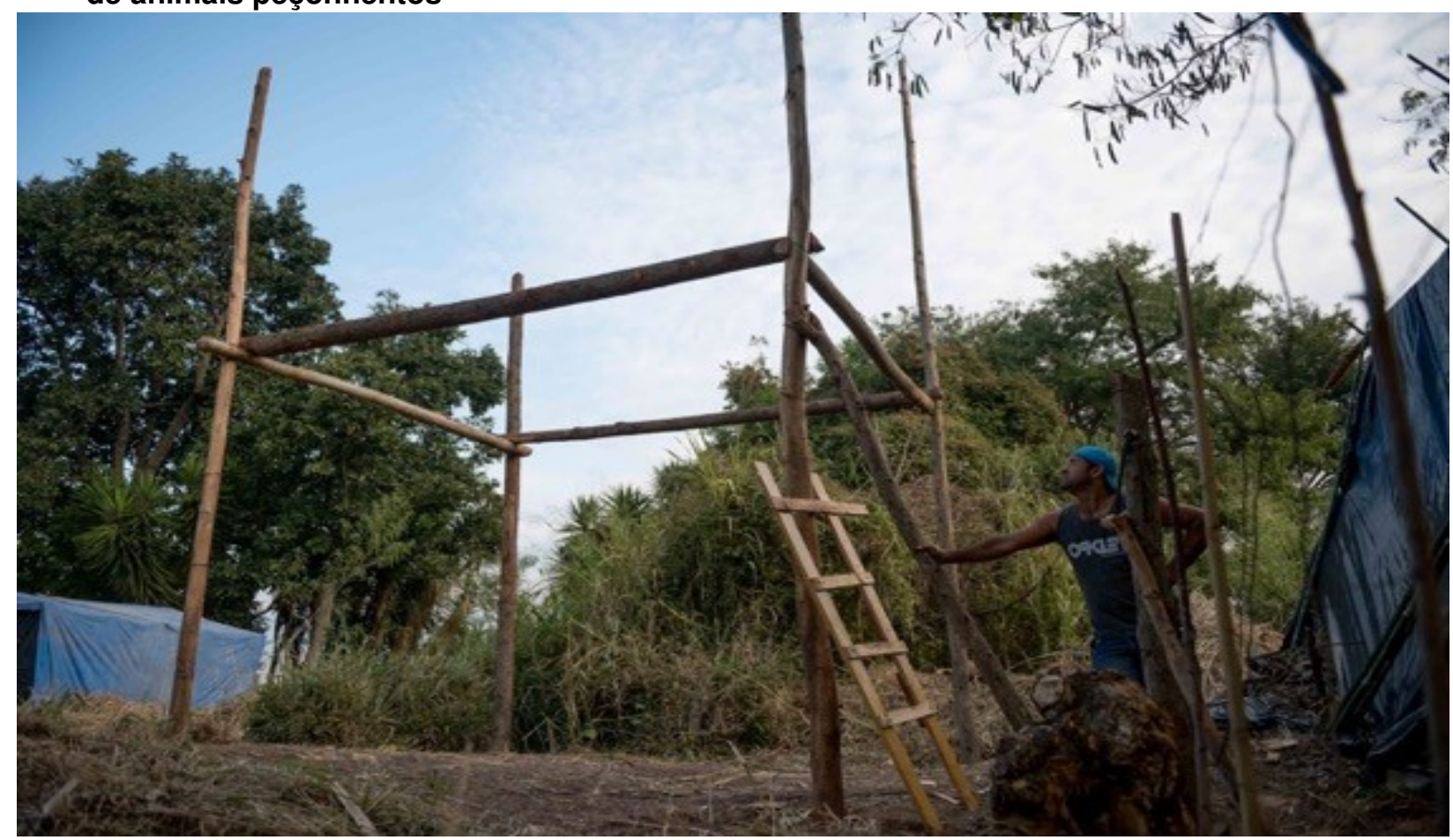

Figura 6. Construção dos barracos: Limpeza dos terrenos e preparação das estruturas

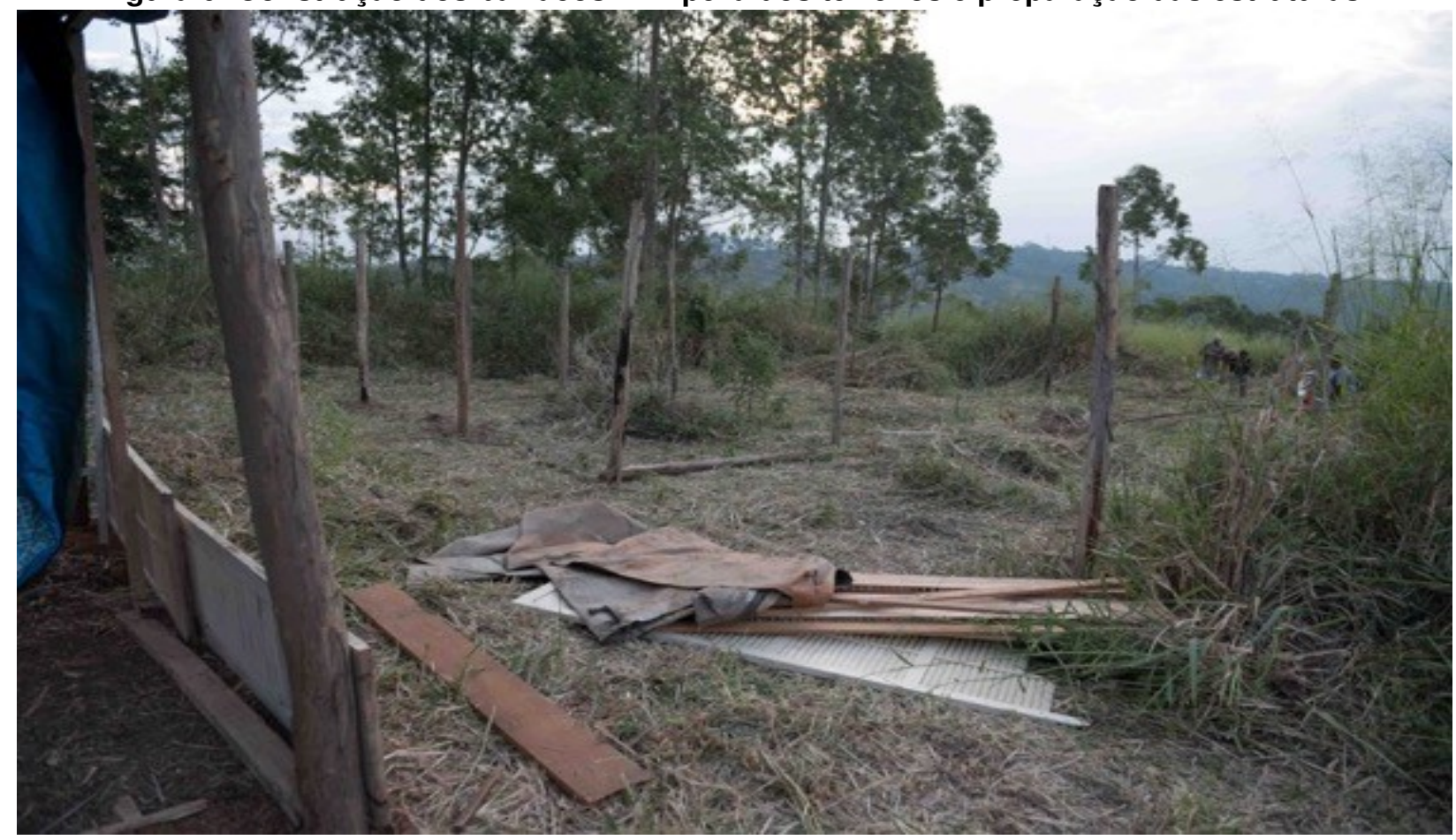


Figura 7. Acampado carrega lenha cortada com técnicas tradicionais para construir barraco.

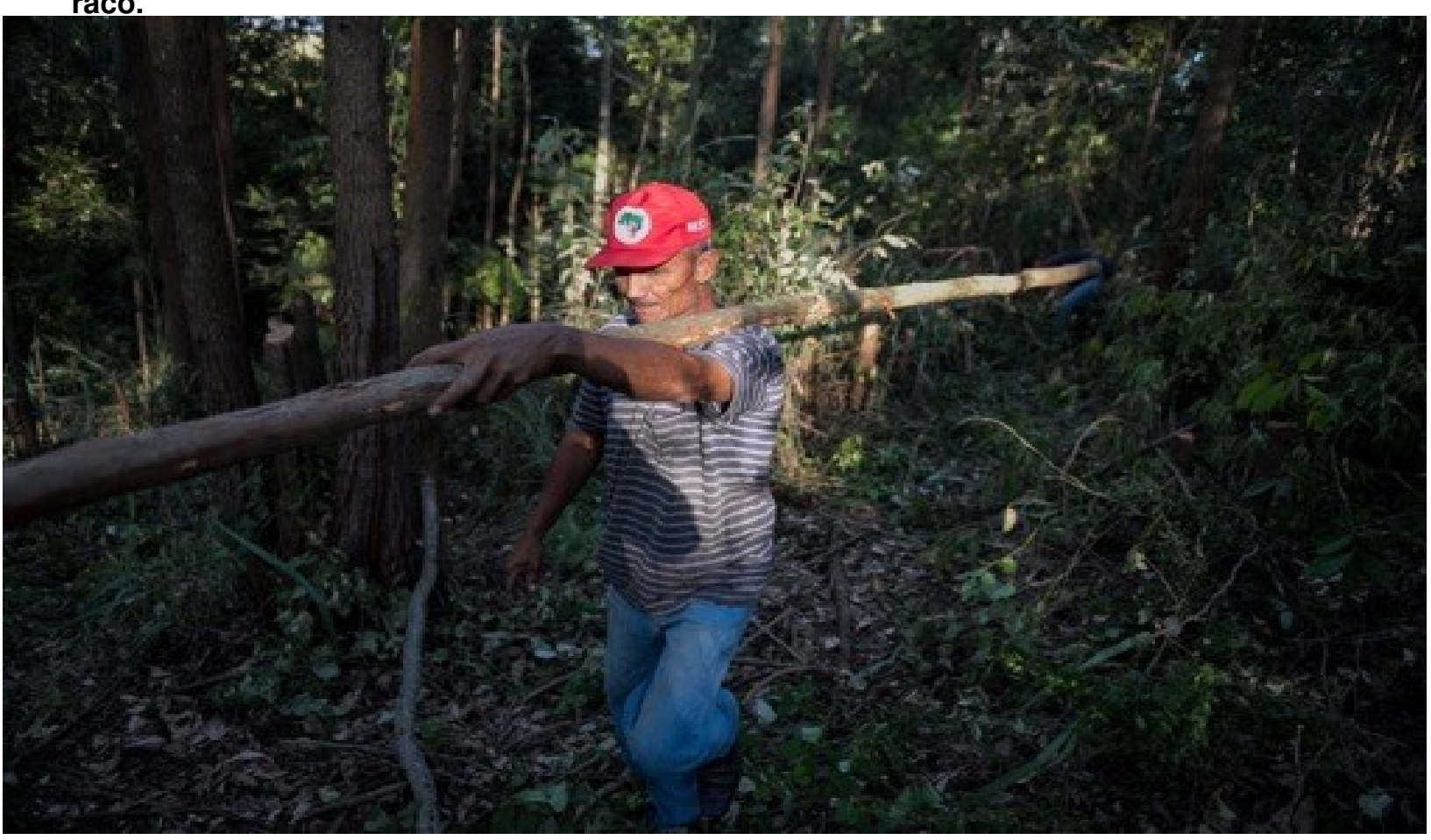

Figura 8. Almoço coletivo entre membros do núcleo de infraestrutura. São os responsáveis pela construção e manutenção dos espaços coletivos do acampamento.

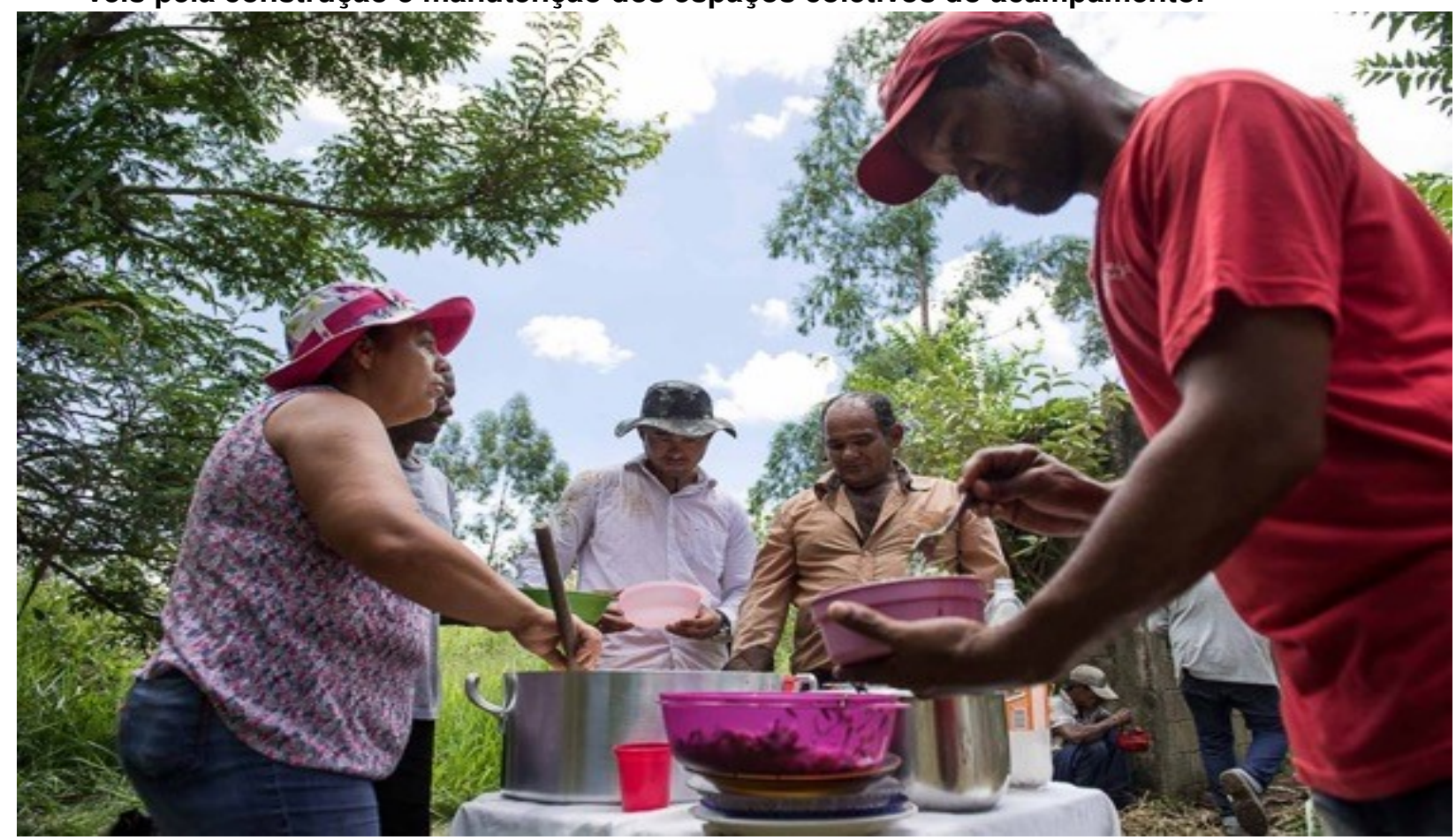


Figura 9. Almoço coletivo entre os membros do núcleo de infraestrutura: o trabalho coletivo é uma das marcas registradas da vida dentro do acampamento.

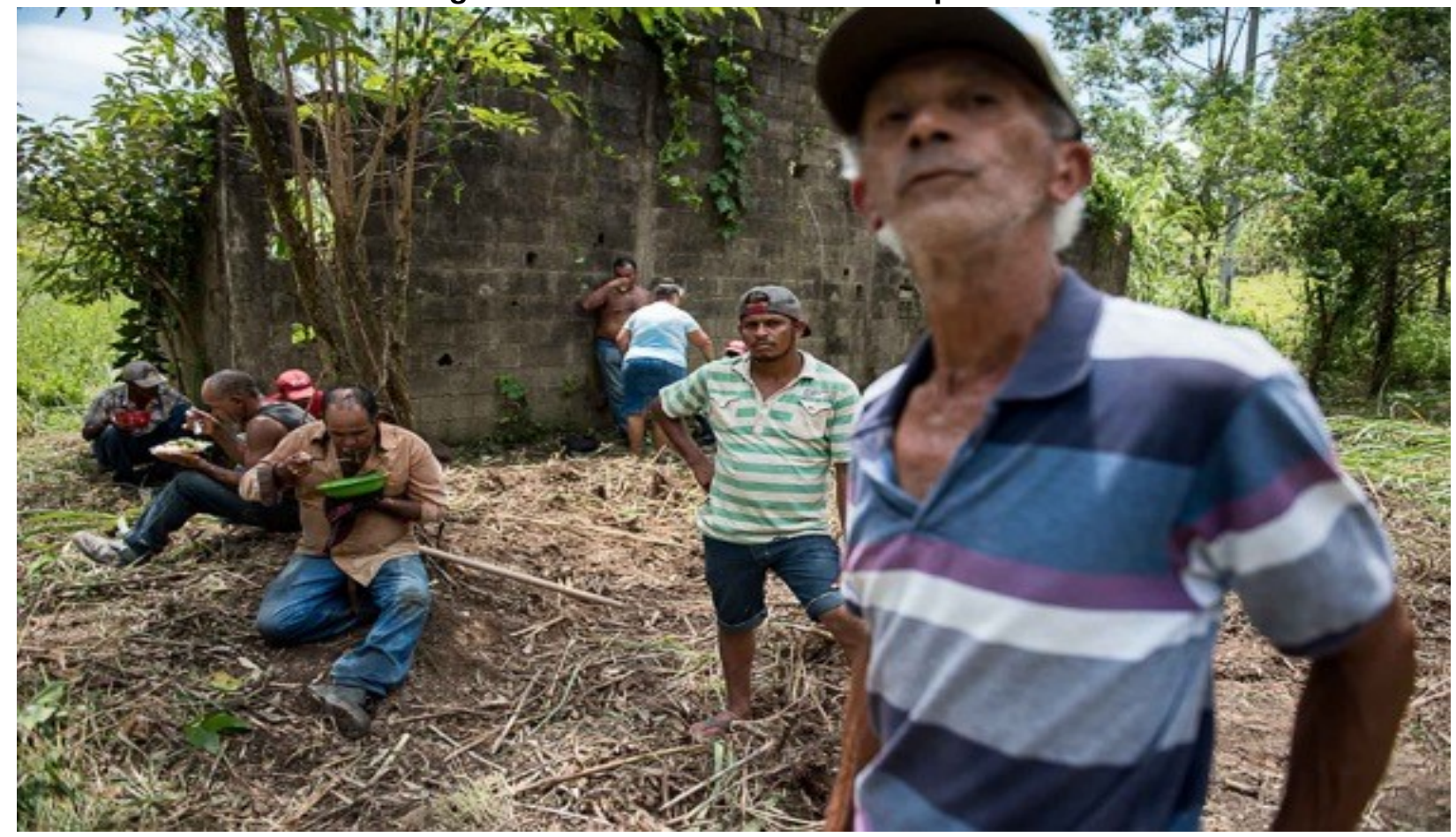

Figura 10. Fogão a lenha onde são feitas diariamente mais de 500 refeições

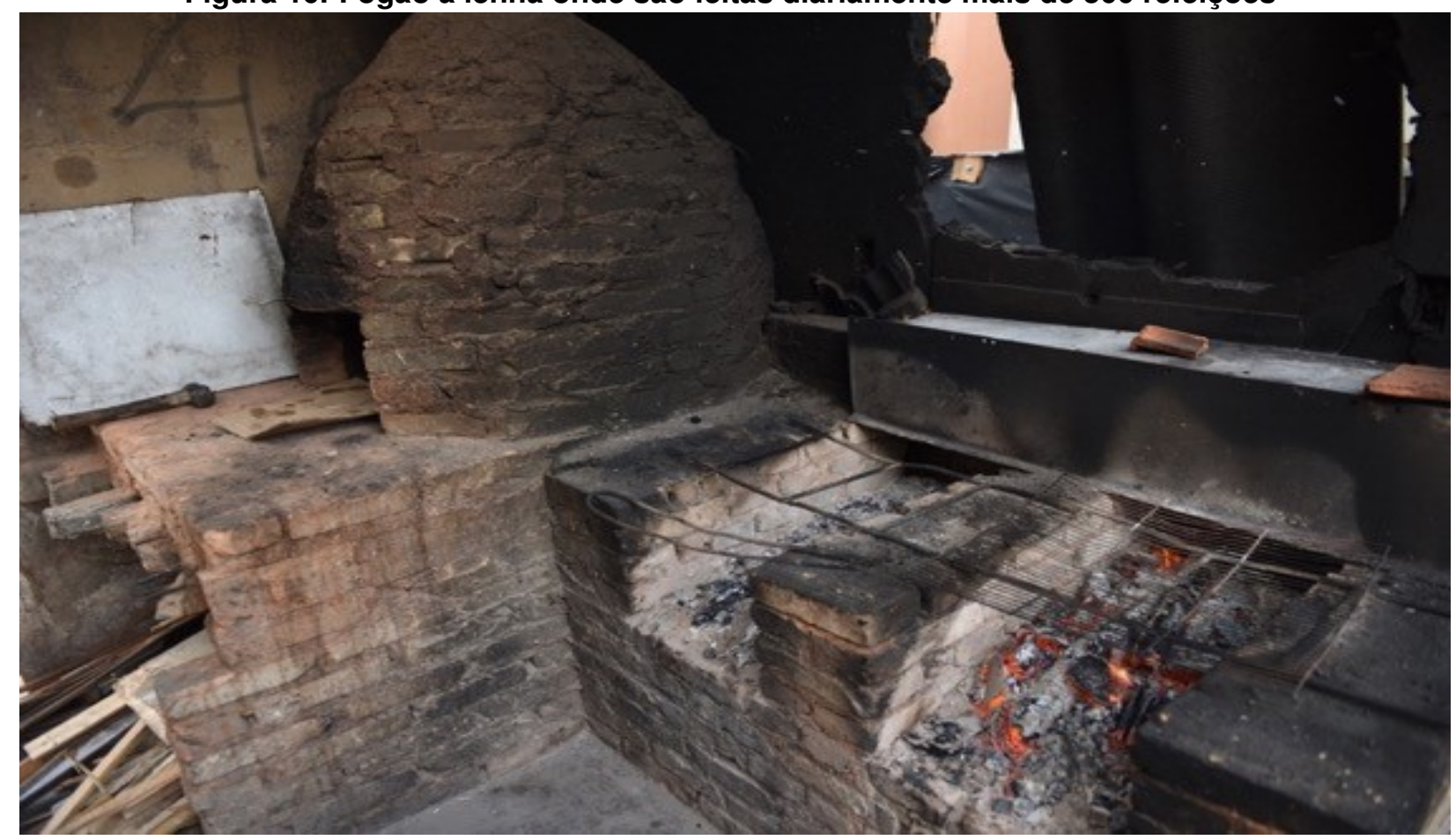


Figura 11. Horários da cozinha coletiva do acampamento

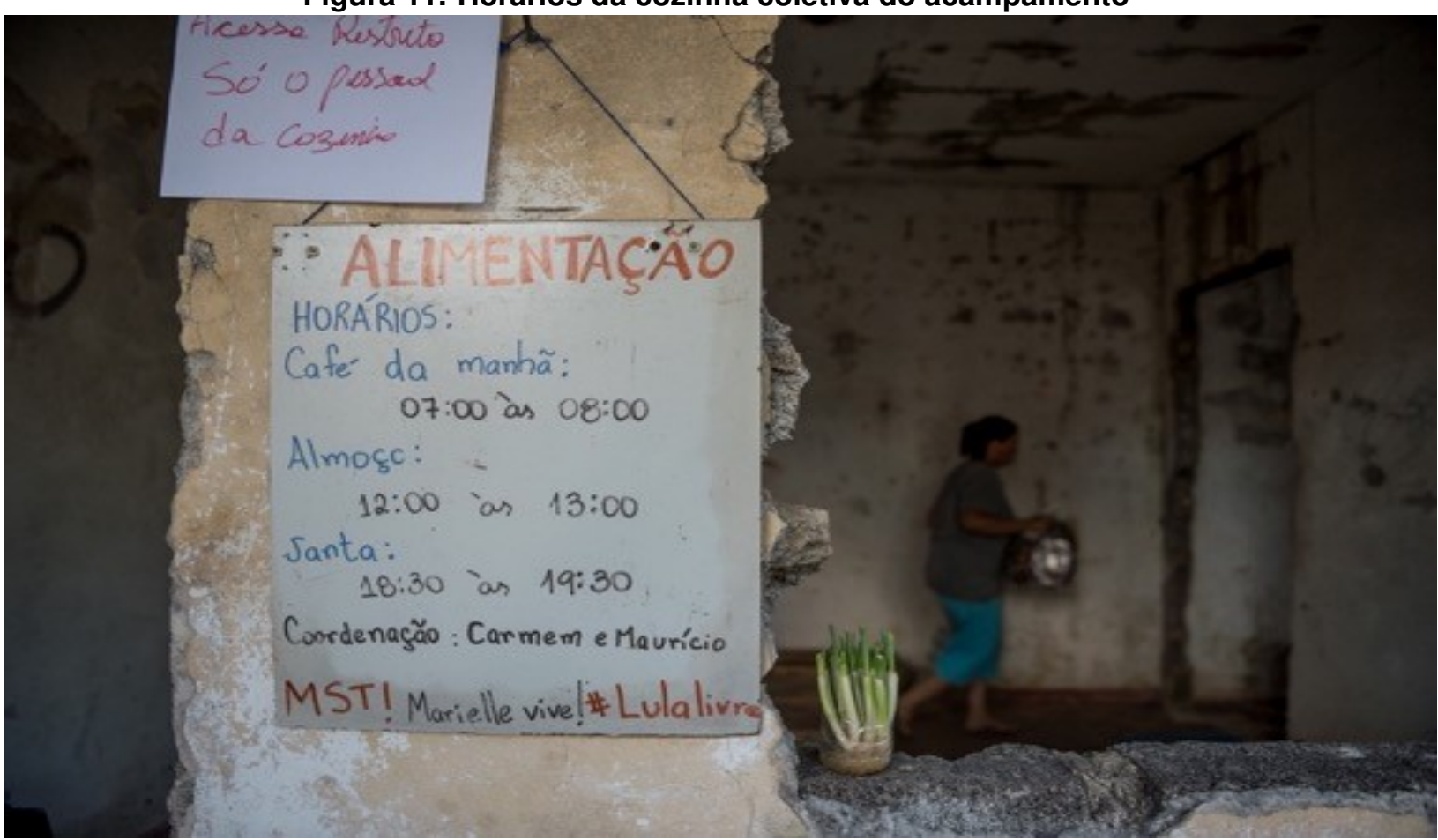

Figura 12. Cupinzeiro transformado em forno pelos acampados

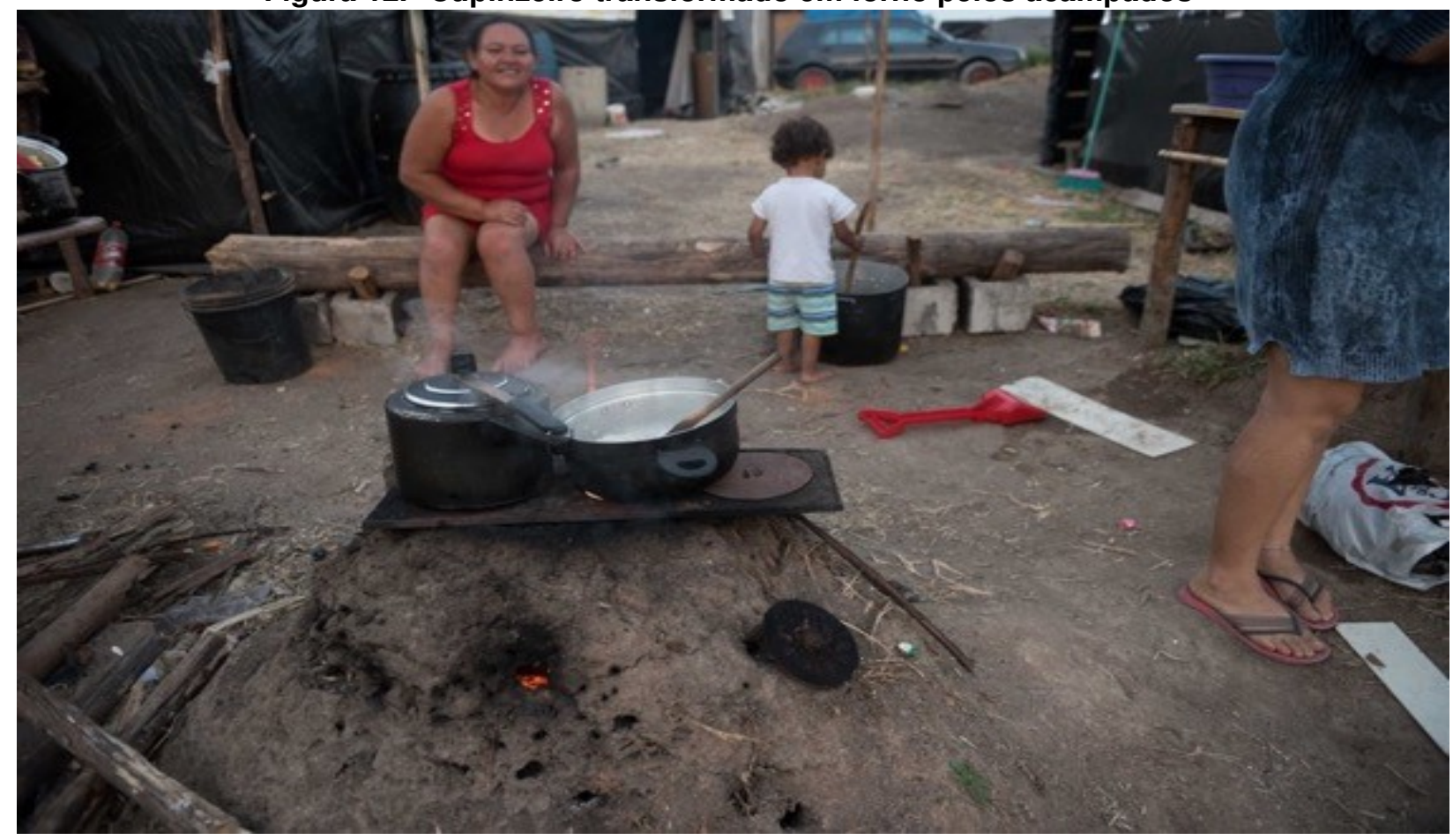


Figura 13. Hortas já dominavam os espaços do acampamento em seus primeiros meses

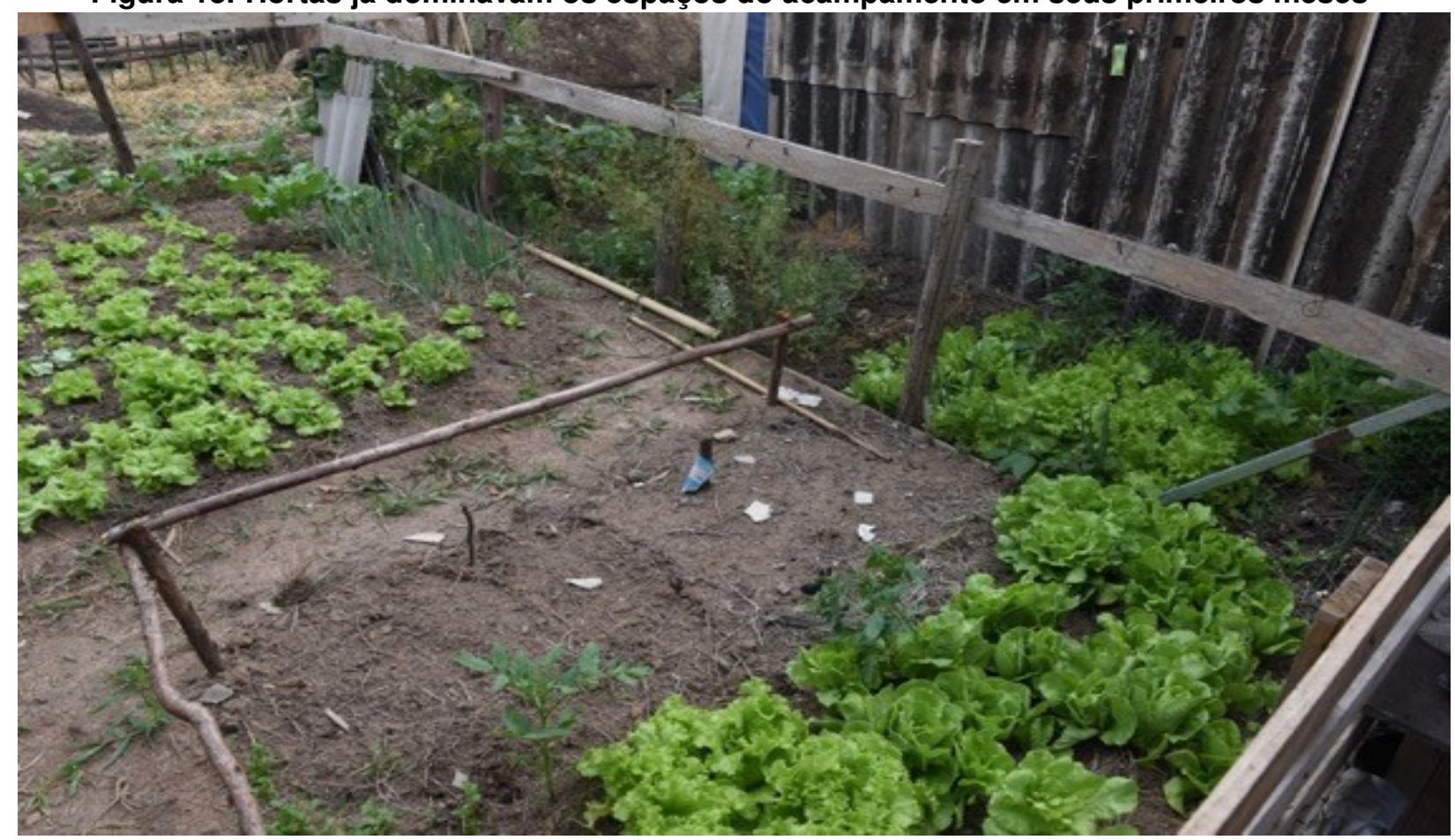

Figura 14. Hortas ocupam os espaços entre os barracos

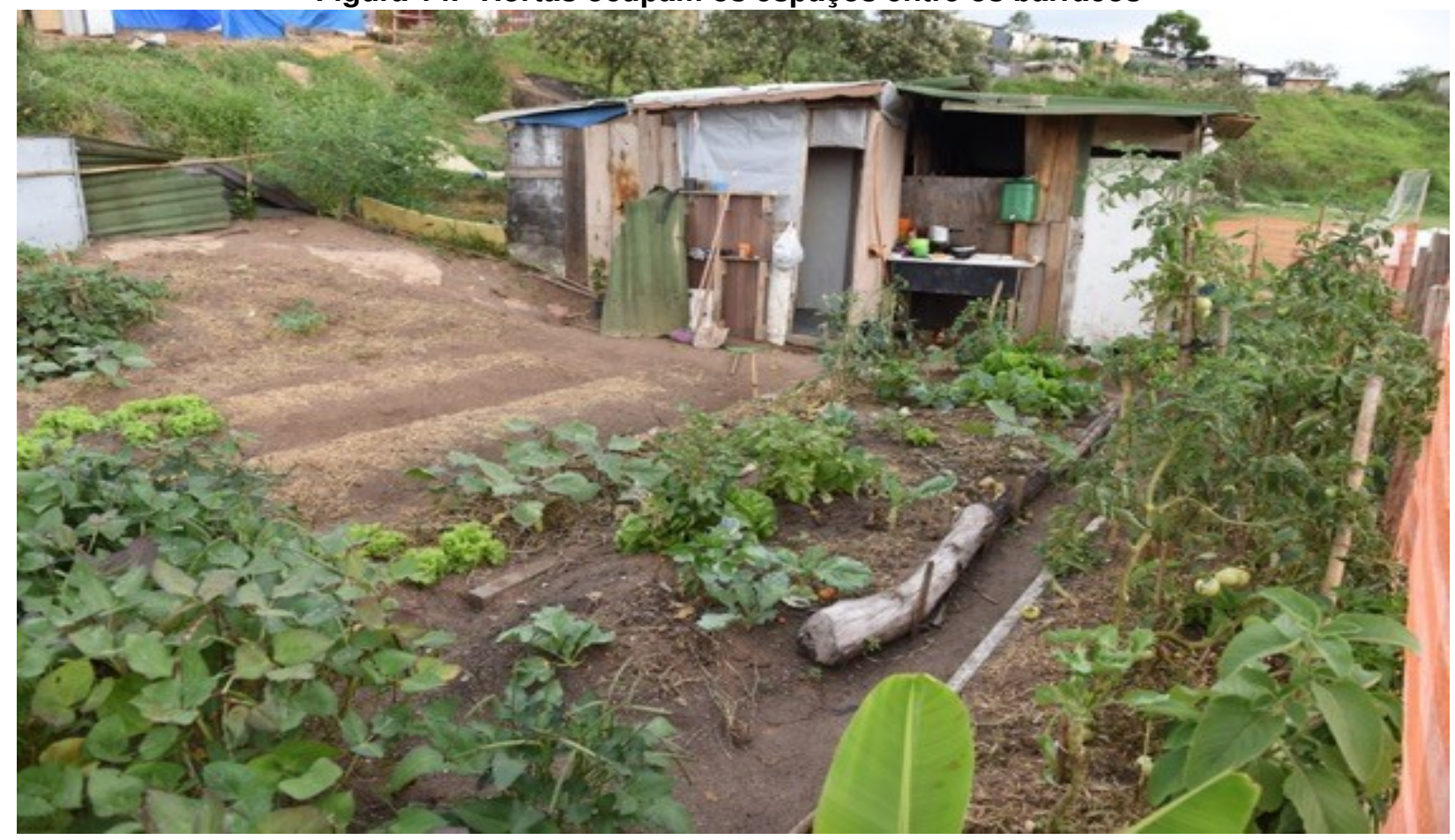


Figura 15. Alguns acampados caminham mais de $\mathbf{2} \mathbf{~ k m}$ diariamente para chegar até a única nascente de água

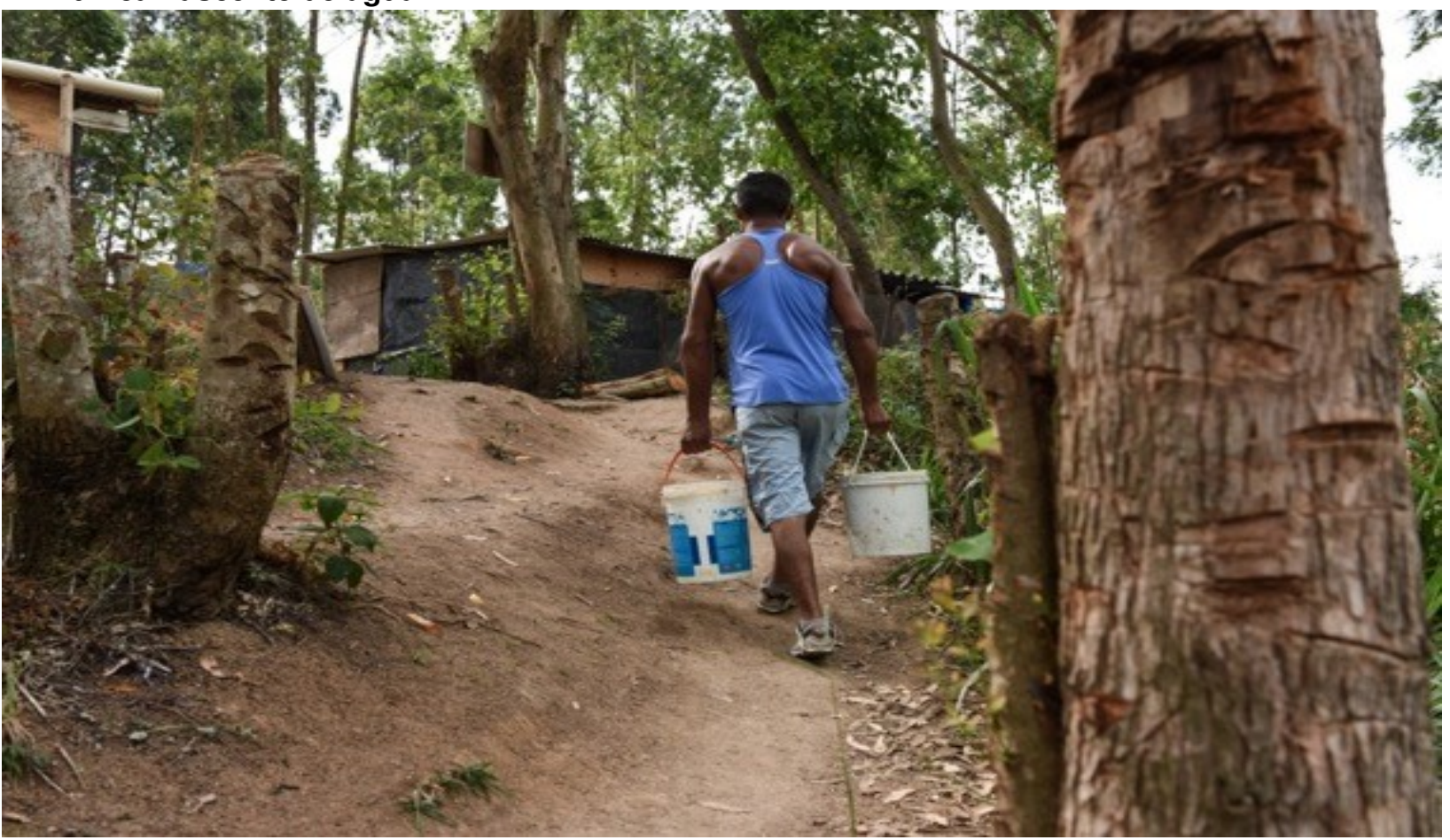

Figura 16. Acampados lavam as roupas na única nascente de água do acampamento

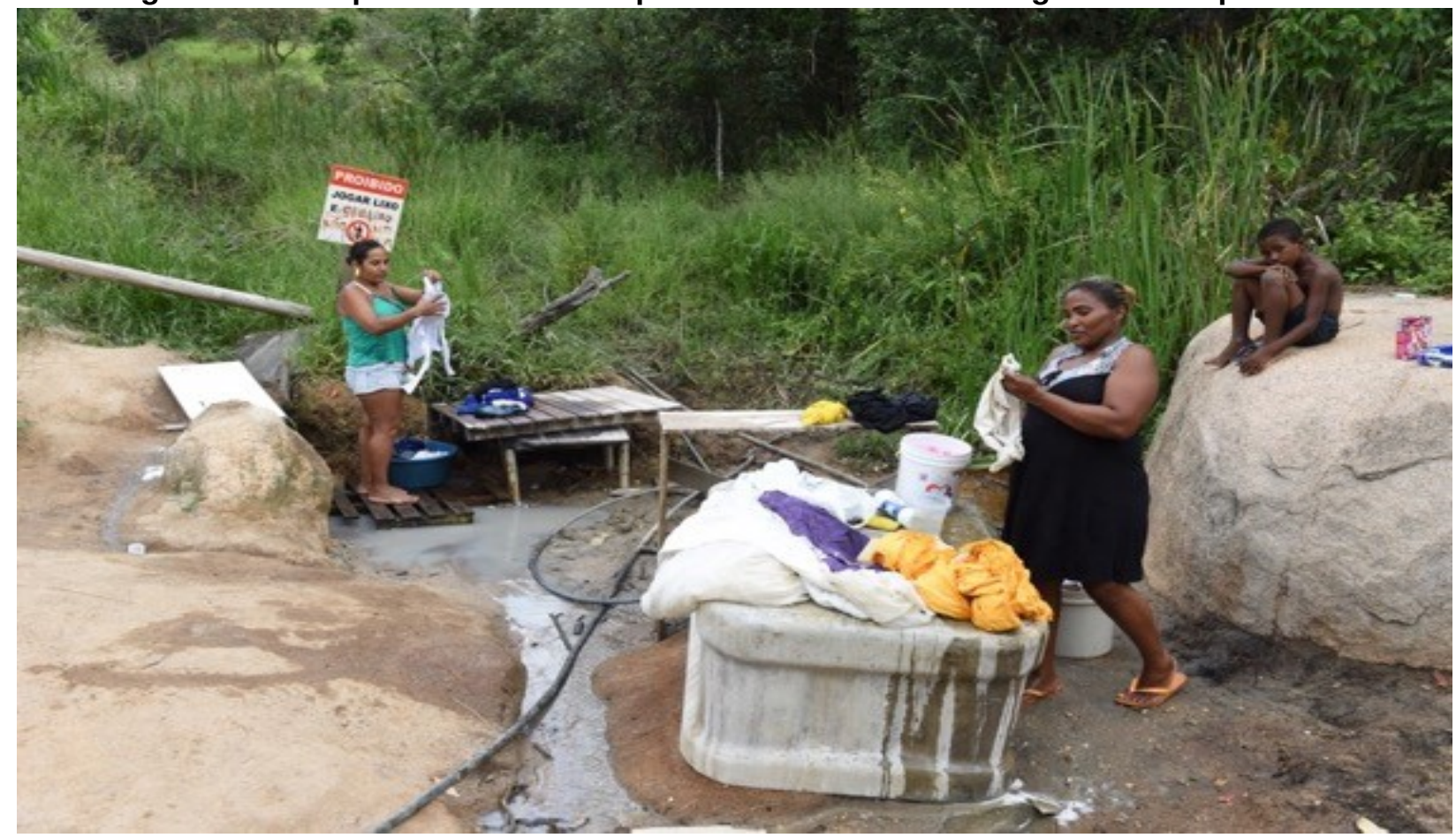


Figura 17. Futebol faz partes das atividades recreativas de jovens e adultos

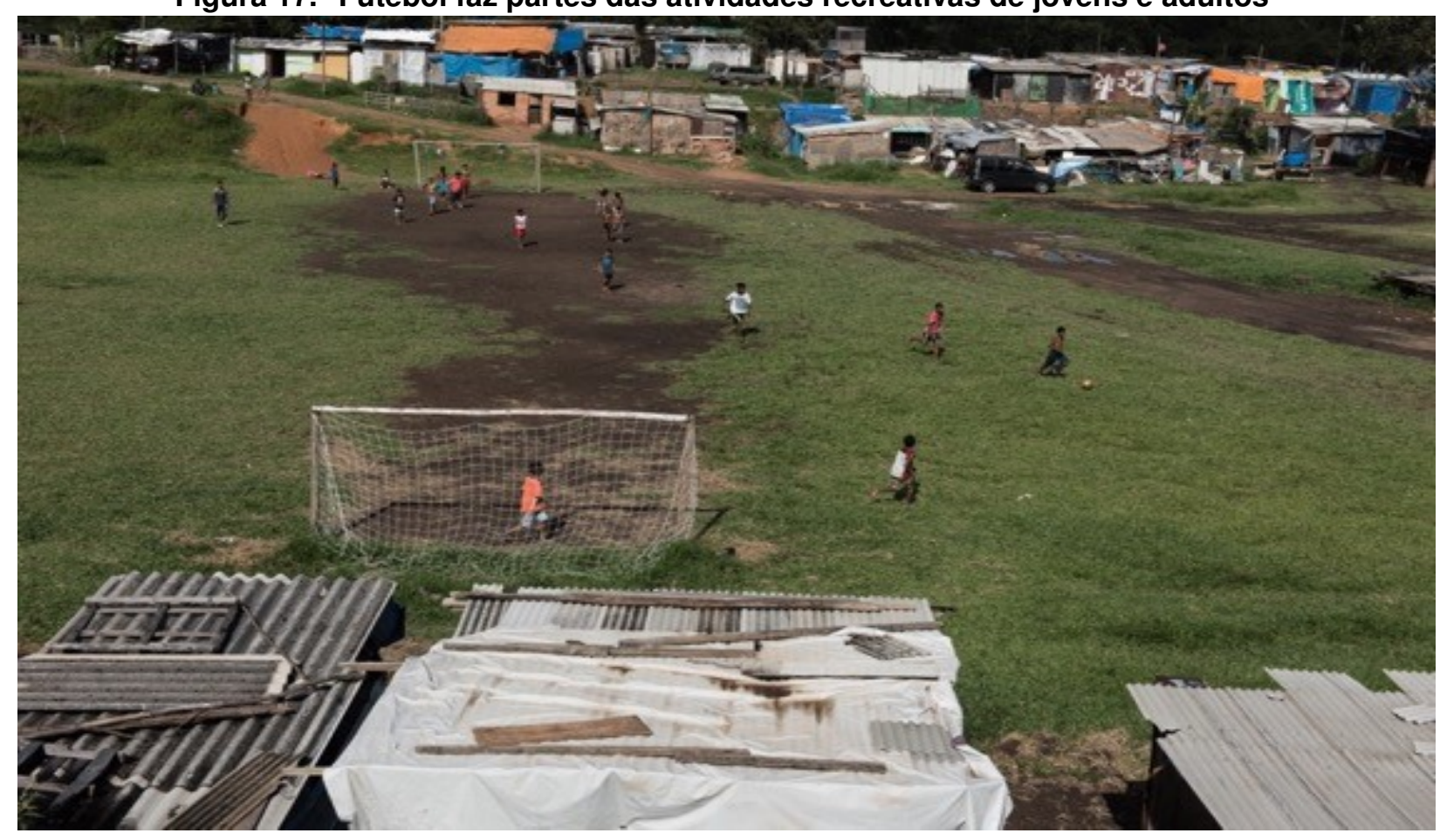

Figura 18. Jogo de futebol: Diversão e interação através do esporte

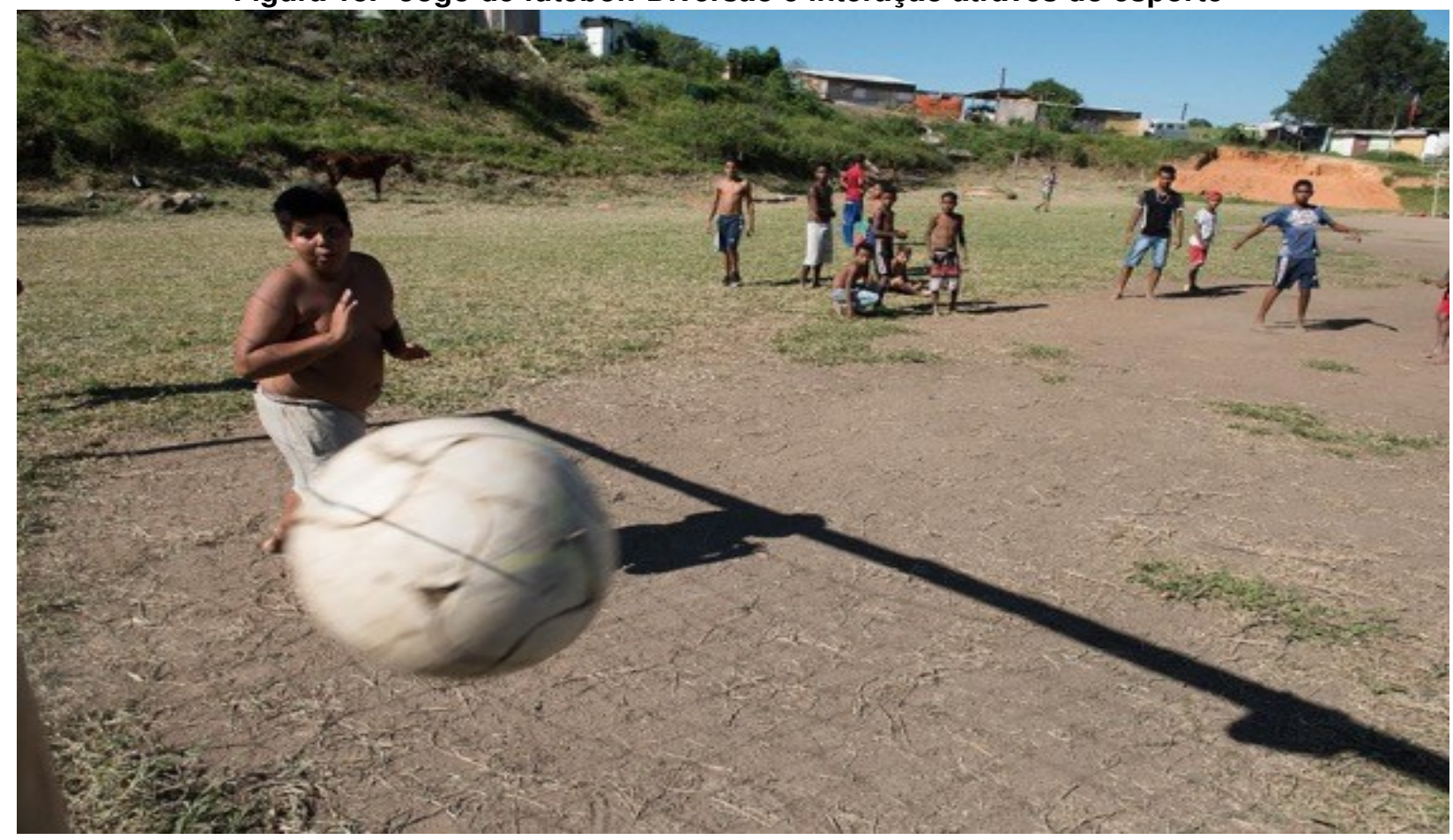


Figura 19. Cantadores

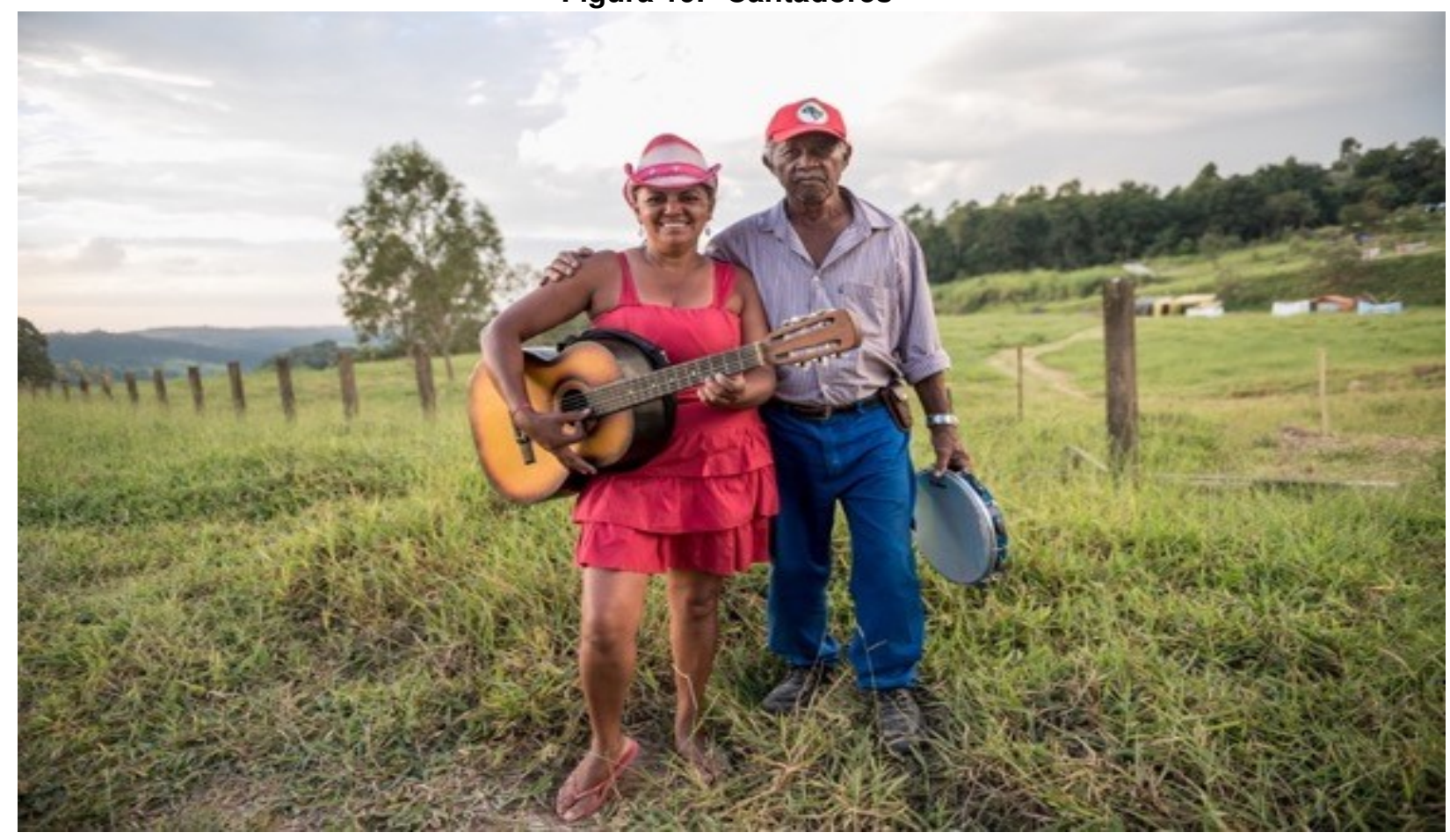

Figura 20. Acampada responsável pela cozinha coletiva, que prepara diariamente mais de 500 refeições

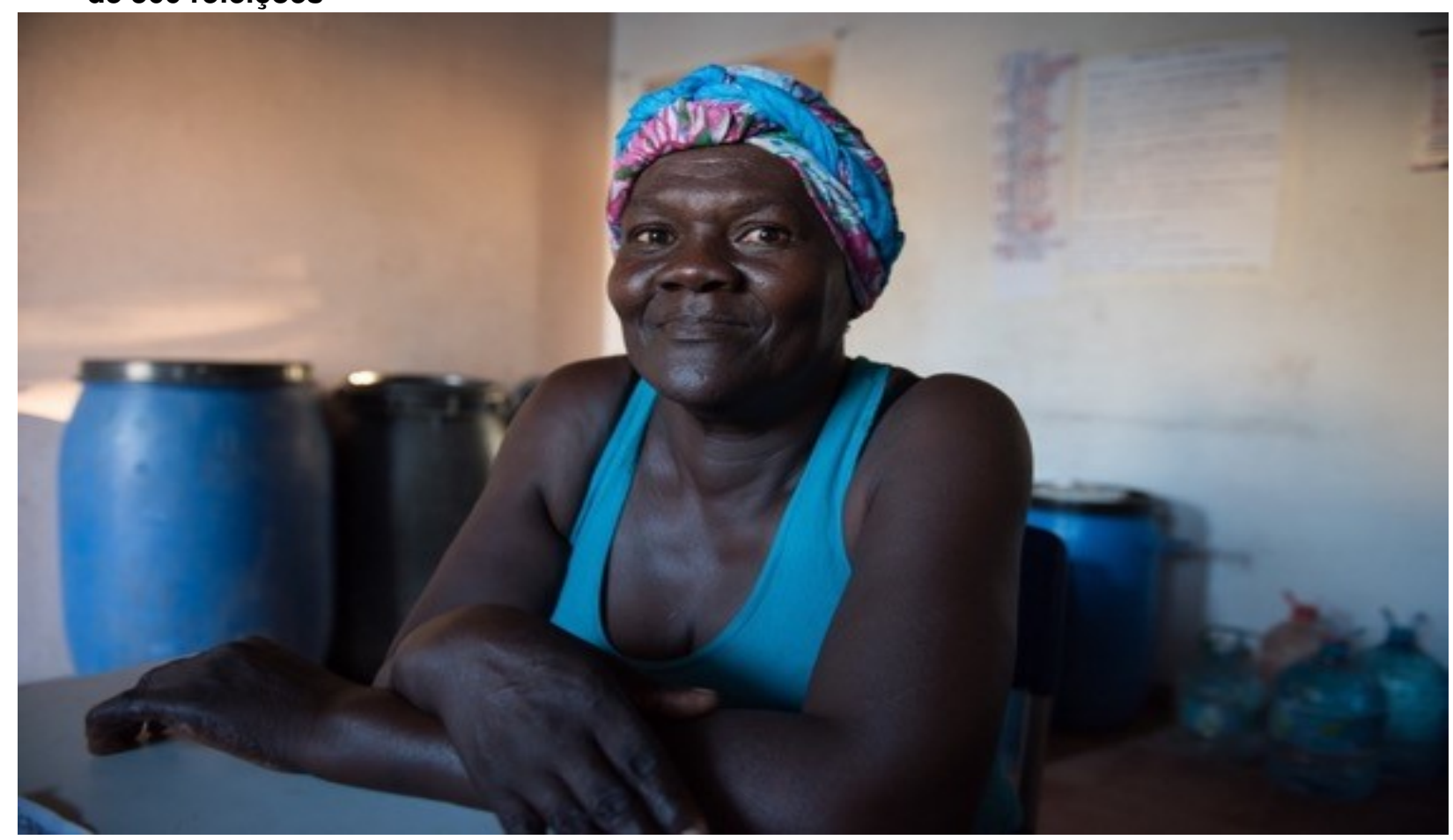


Figura 21. Músicas sertanejas são parte diária das atividades dos acampados

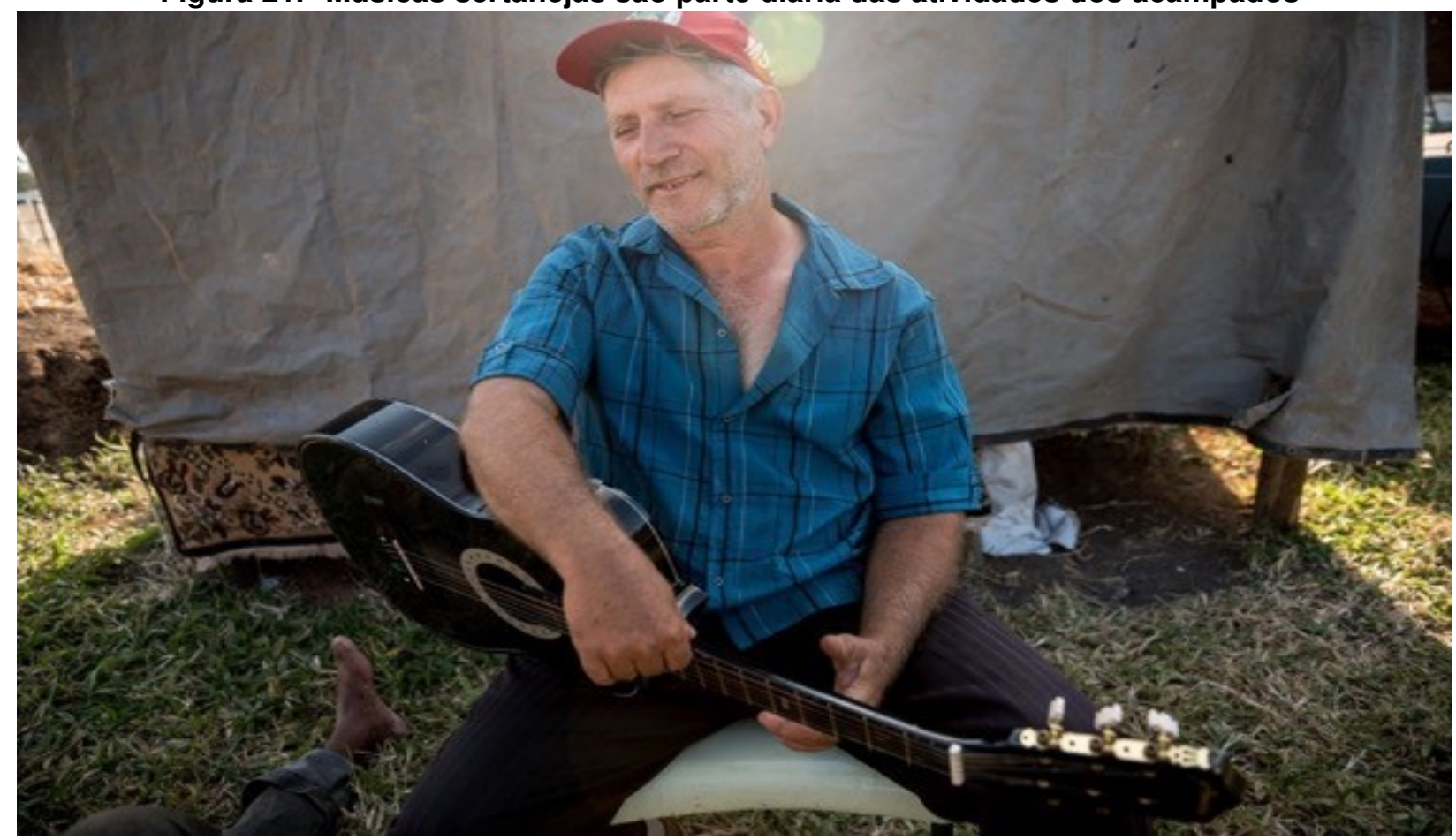

Figura 22. Encontro para tomadas coletivas de decisão

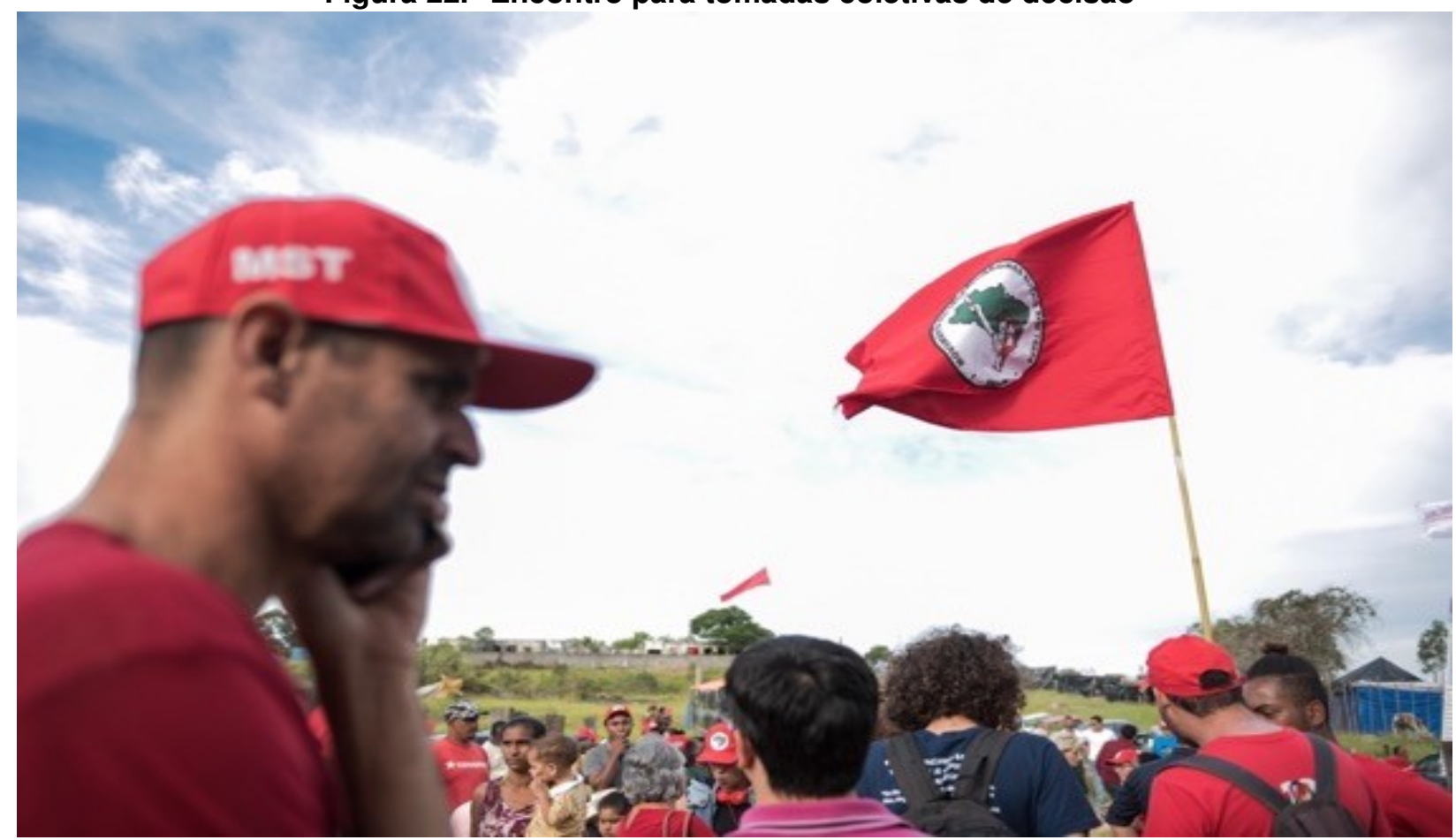


Figura 23. Assembleia coletiva onde importantes decisões são tomadas coletivamente.

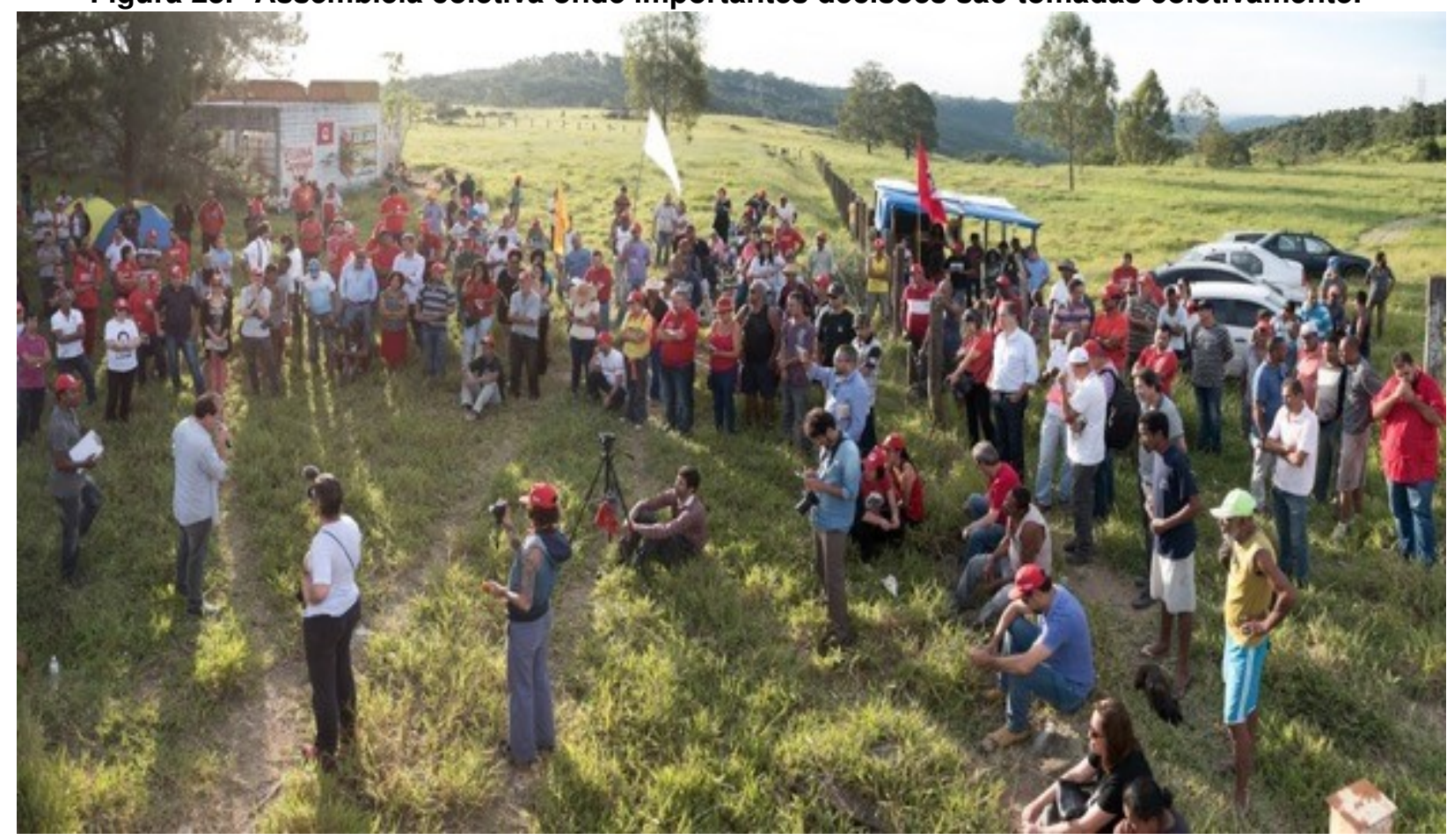

Figura 24. Participantes da assembleia

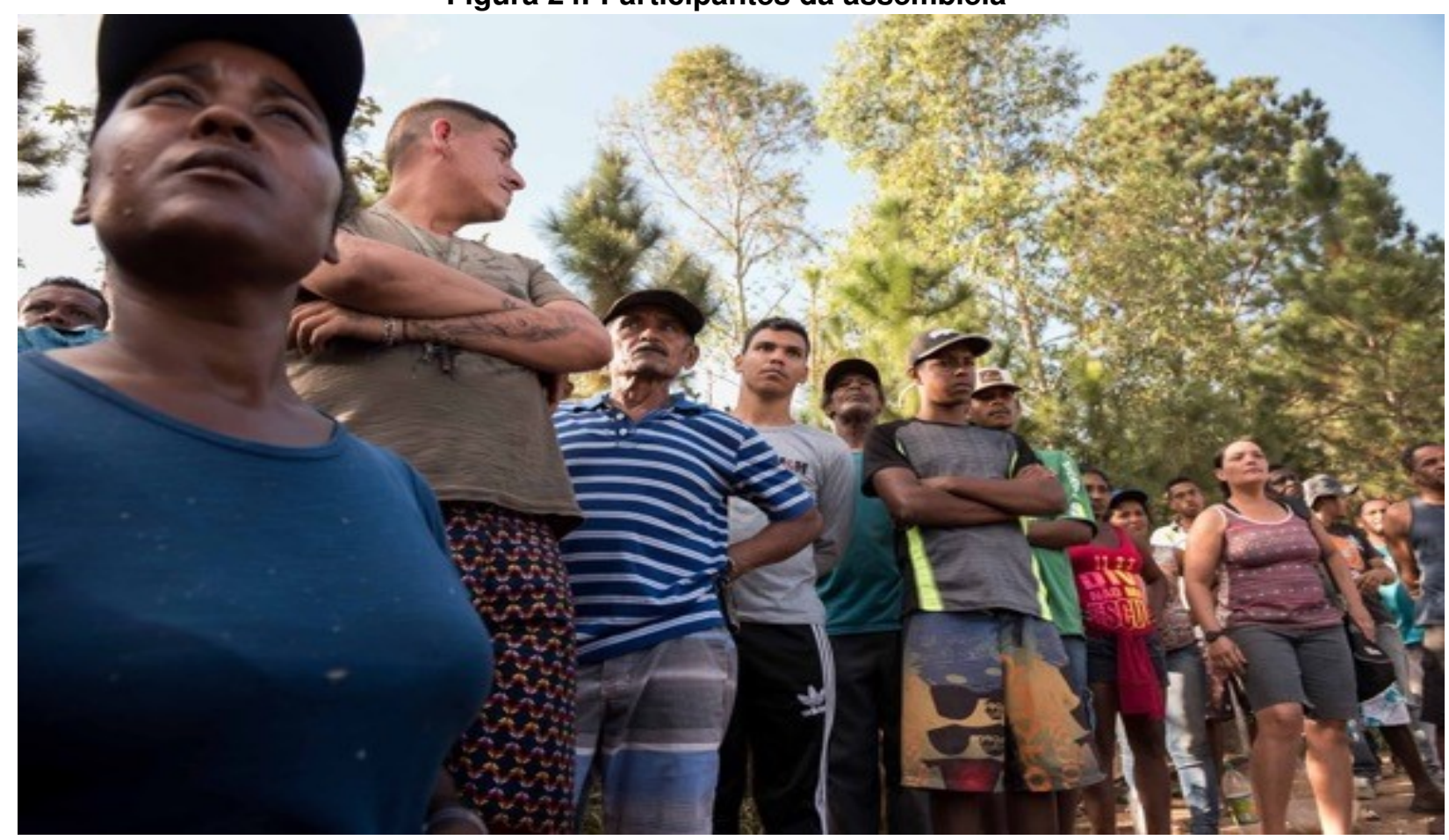


Figura 25. Panoramas do Acampamento

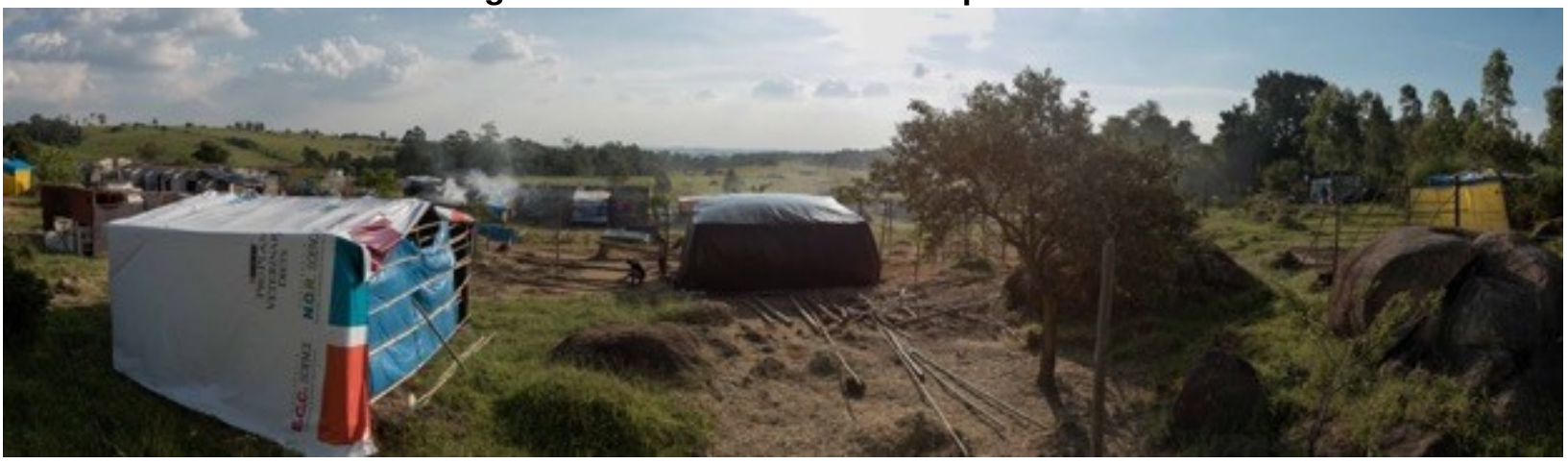

Figura 26. Panoramas do acampamento

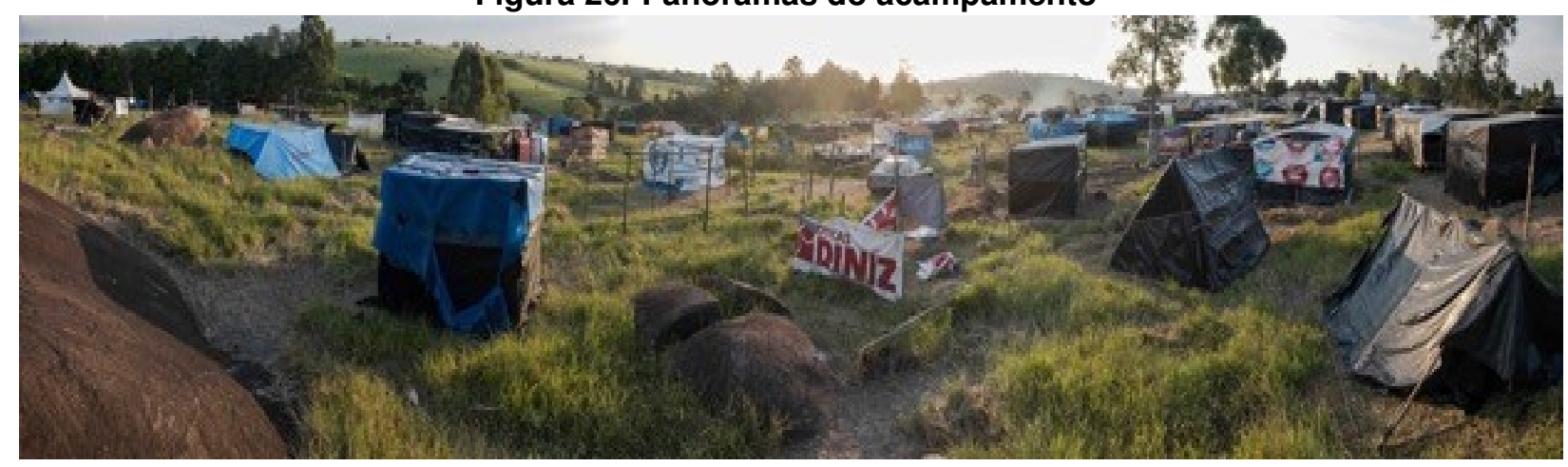

Figura 27. Panoramas do acampamento

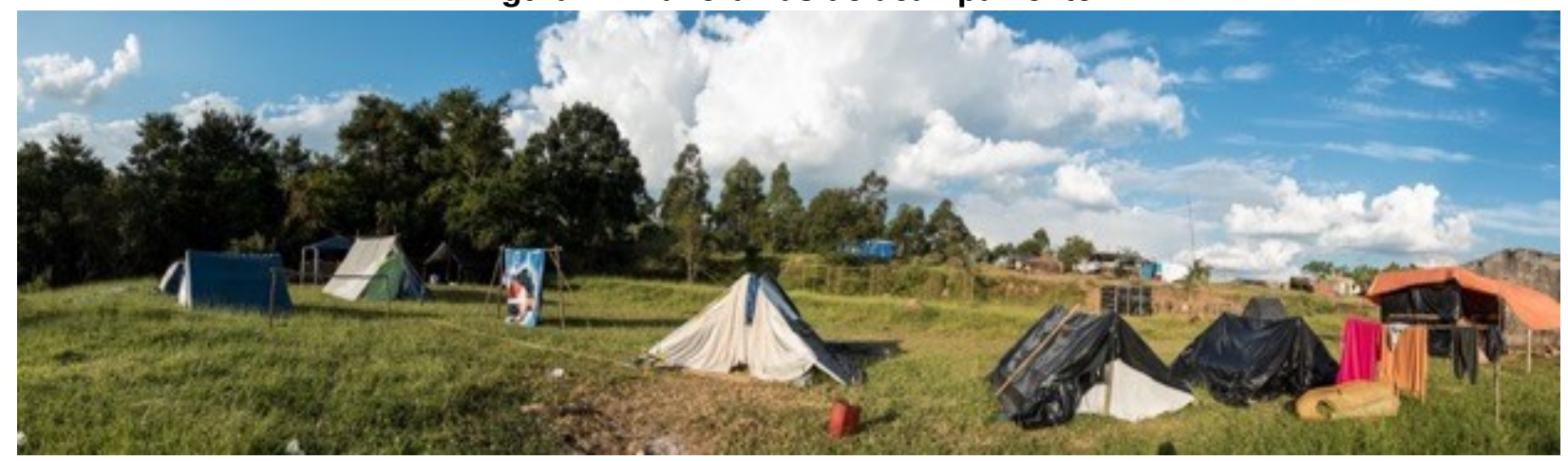

